\title{
Preserving amortized costs within a fair-value- accounting framework: reclassification of gains and losses on available-for-sale securities upon realization
}

\author{
Minyue Dong • Stephen Ryan • Xiao-Jun Zhang
}

Published online: 28 August 2013

(C) Springer Science+Business Media New York 2013

\begin{abstract}
SFAS No. 115 requires firms to recognize available-for-sale (AFS) securities at fair value with accumulated unrealized gains and losses (AUGL) recorded in accumulated other comprehensive income. Firms reclassify AUGL to net income when they realize gains and losses. We refer to the amount reclassified each period by "RECLASS." As of 1998, SFAS No. 130 requires firms to present RECLASS prominently in their financial statements. We investigate the incremental explanatory power of RECLASS for banks' market values and market-adjusted returns. In the market value analysis, we control for AUGL, other components of book value of equity, net income before extraordinary items and RECLASS $\left(\right.$ NIBEX $^{\text {other }}$ ), and other components of comprehensive income. In the returns analysis, we control for $\triangle \mathrm{AUGL}, \triangle \mathrm{NIBEX}^{\mathrm{other}}$, and extraordinary items. We find high positive coefficients on RECLASS in both analyses, consistent with investors pricing RECLASS as a relatively permanent component of net income. Exploring possible explanations for these pricing implications, we find no evidence that they
\end{abstract}

M. Dong $(\bowtie)$

Faculty of Business and Economics, University of Lausanne, UNIL-Dorigny, Building Internef, 1015 Lausanne, Switzerland e-mail: minyue.dong@unil.ch

S. Ryan

Stern School of Business, Kaufman Management Center, 44 West 4th Street, New York, NY 10012, USA

e-mail: sryan@stern.nyu.edu

X.-J. Zhang

Haas School of Business, University of California, 545 Student Services Building \#1900, Berkeley, CA 94720, USA

e-mail: xzhang@haas.berkeley.edu 
are attributable to RECLASS remedying unreliable fair value measurement of AUGL. We provide three distinct analyses indicating that RECLASS's pricing implications are explained in significant part by it helping investors predict banks' future performance. Our results illustrate that an important type of amortized cost accounting information, realized gains and losses, remains highly useful to investors despite the overall fair-value-accounting framework for AFS securities.

Keywords Available-for-sale securities · Reclassification · Fair value accounting $\cdot$ Realization

JEL classification $\quad \mathrm{G} 21 \cdot \mathrm{M} 41$

\section{Introduction}

We investigate the incremental explanatory power of realized gains and losses on available-for-sale (AFS) securities for commercial banks' market value of equity (market value) and market-adjusted returns (returns), controlling for accumulated unrealized gains and losses on those securities (AUGL) and the other components of book value of equity and comprehensive income. We focus on AFS securities because US GAAP requires firms to recognize these securities at fair value on their balance sheets but to report amortized cost information about realized gains and losses on the securities on their income statements through the use of "dirty surplus" accounting described below. This contrasts with the typical financial reporting for financial instruments, in which one of fair value and amortized cost information is reported only in footnote disclosures or not at all. Prior research shows that investors react more strongly to amounts that are recognized in financial statements rather than disclosed elsewhere in financial reports, either because investors cannot or do not evaluate the disclosures or because they deem recognized amounts more reliable (Schipper 2007). Hence AFS securities constitute a clean setting to evaluate the pricing implications of amortized cost and fair value information about financial instruments.

Statement of Financial Accounting Standards (SFAS) No. 115, Accounting for Certain Investments in Debt and Equity Securities, requires a hybrid fair-value-onthe-balance-sheet and amortized-cost-on-the-income-statement approach to accounting for AFS securities. Firms record AFS securities on the balance sheet at fair value, with AUGL recorded in accumulated other comprehensive income (AOCI), a component of owners' equity distinct from retained earnings. This constitutes dirty surplus accounting because changes in owners' equity occur without corresponding changes in net income. Subsequently, firms reclassify AUGL to net income when gains and losses are realized economically through sale of AFS securities or for accounting purposes through transfer of the securities to trading or other-than-temporary (OTT) impairment write-downs. This reclassification of gains and losses upon realization is often referred to as "recycling"; we denote the amount reclassified each period by "RECLASS." 
Fair value accounting advocates criticize this accounting, particularly for liquid AFS securities for which fair value is both reliably measured and a more relevant measurement attribute than amortized cost. ${ }^{1}$ Even if unrealized gains and losses are reliably measured, however, amortized cost information may be incrementally useful for investment and other purposes. The FASB acknowledges this point in its May 2010 Exposure Draft, Accounting for Financial Instruments and Revisions to the Accounting for Derivative Instruments and Hedging Activities, stating that amortized costs may be relevant because of their association with contractual cash flows or correspondence with firms' business strategies. ${ }^{2}$

Critics of fair value accounting raise two opposing concerns. First, they question the reliability of unrealized gains and losses, at least in some circumstances, either in absolute terms (e.g., Wallison 2008 and Forbes 2009) or relative to the certain measurement of realized gains and losses (Abdel-Khalik 2008). In our view, reliability of measurement is a relatively minor concern for most of banks' AFS securities, which are primarily governmental and other liquid securities, although it is a significant concern for some structured asset-backed and other illiquid securities. ${ }^{3}$ Second, and more interestingly, some critics of fair value accounting point out that financial reporting of realized amounts (of which realized gains and losses on securities are only one type) is useful for various purposes, such as contracting and stewardship assessment (Watts 1993; Holthausen and Watts 2001), capital regulation (Khan 2010), and portraying firms' business strategies (Nissim and Penman 2008). Providing a rubric for this usefulness, Ronen (2008) states that "accounting should ... provide information about the realization of expectations ... [to help investors in] assessing the reliability of expectations and the quality of management performance, as well as in facilitating the improvement of the forecasting process."

Consistent with this statement, we expect RECLASS to help investors predict future bank performance for two compatible reasons. First, a longstanding literature

\footnotetext{
${ }^{1}$ Schultz and Hollister (2003) and Johnson and Swieringa (1996) describe the political process and resulting compromises involved in gaining general acceptance for SFAS No. 115. Interestingly, these compromises occurred despite considerable support for fair value accounting for all investment securities from SEC Chairman Richard Breeden (see his September 14, 1990, speech, "The Proper Role of Financial Reporting: Market Based Accounting," at Smith Barney's Fourth Annual Financial Services Conference in Washington, DC, available on the SEC website) and many bank regulators because the thrift crisis had recently revealed the limitations of amortized cost accounting. Notably, however, Federal Reserve Board Chairman Alan Greenspan strongly opposed this change in accounting (see his November 1, 1990, letter to Richard Breeden, available http://economyblog.ncpa.org/wp-content/plugins/uploads/ Greenspan\%201etter\%20to\%20SEC\%20November\%201990.pdf).

2 See the "What are the Main Aspects of the Proposed Guidance?" section on pp. 3-5 and paragraphs BC57, BC58, and BC79 of the May 2010 exposure draft. In its redeliberations of the exposure draft to date, the FASB proposes to require parenthetical presentation on the balance sheet of fair values for most financial instruments measured at amortized cost and of amortized costs for financial liabilities (but not financial assets) measured on fair value. See Financial Accounting Standards Board, Accounting for Financial Instruments: Summary of Decisions Reached to Date during Redeliberations as of June 20, 2012, available on the FASB website.

3 Trevor Harris points out that securities typically viewed as highly liquid may experience significant price pressures due to financial institutions' concentrated and correlated trading behavior at certain times. This behavior may occur at the end of accounting periods due to performance evaluation of employees, end-of-period financial statement window dressing, or other reasons.
} 
finds that banks realize gains and losses on AFS securities to smooth their reported net income. ${ }^{4}$ To the extent this occurs, RECLASS makes reported net income more permanent and thus more indicative of future income. ${ }^{5}$ Second, RECLASS should help investors evaluate the reliability of the reported fair values of banks' AFS securities and thus help them predict future income on these securities.

We hand-collected RECLASS for the 200 largest publicly traded US commercial banks (based on total assets in 1998) for the period 1998-2006. We limit our sample to banks because total (realized) gains and losses on AFS securities often constitute significant portions of their owners' equity (net income). Our sample period begins in 1998, when SFAS No. 130, Reporting Comprehensive Income, required firms to disclose RECLASS prominently in financial statements. ${ }^{6}$

We estimate both market value and returns models, because the former contains less noisy explanatory variables but is more prone to scale-related specification problems than the latter. The empirical results for the two models are consistent, indicating that neither type of specification issue drives our results. Motivated by Ohlson (1995), the market value model controls for AUGL, other components of book value of equity, net income before extraordinary items, discontinued operations, and RECLASS (NIBEX ${ }^{\text {other }}$ ), extraordinary items and discontinued operations (EX), $\triangle$ AUGL, and other components of other comprehensive income. Similar to Badertscher et al. (2012), who examine the related setting of OTT impairment write-downs of investment securities, the returns model controls for $\triangle \mathrm{NIBEX}^{\mathrm{other}}, \mathrm{EX}, \triangle \mathrm{AUGL}$, and other components of other comprehensive income.

Our primary findings are as follows. First, we find at least normal pricing implications for AUGL in the market value model and $\triangle$ AUGL in the returns model. For example, in the market value model the coefficient on AUGL is larger than the coefficient on the amortized cost of AFS securities. We interpret these findings as implying that RECLASS's pricing implications are not primarily attributable to it remedying unreliable fair value measurement of $(\Delta)$ AUGL.

Second, we find that the coefficients on RECLASS significantly exceed one and are closer to the coefficients on relatively permanent NIBEX $^{\text {other }}$ in the market value model and $\triangle \mathrm{NIBEX}^{\mathrm{other}}$ in the returns model than to the coefficients on the more transitory components of comprehensive income. Our remaining analyses investigate possible explanations for RECLASS's high pricing implications.

Third, we consider the possibility that unrealized gains and losses are unreliable, as critics of fair value accounting often allege, and that RECLASS remedies this unreliability. This possibility is inconsistent with our findings for $(\Delta)$ AUGL and

\footnotetext{
${ }^{4}$ See Scholes et al. (1990), Beatty et al. (1995), Collins et al. (1995), Beatty et al. (2002), Cornett et al. (2009), and Chang et al. (2011).

5 Realization of gains and losses on AFS securities is only one of banks' primary mechanisms for income management, along with the provision for loan losses, realization of gains and losses on other assets and liabilities, and Level 2 and 3 fair value estimates for trading and other positions for which unrealized gains and losses are recorded in net income. As discussed in Sect. 4, we find that RECLASS offsets a significant but relatively small portion of the variation in net income.

${ }^{6}$ From 1993 to 1997, users of financial reports generally could have, with some effort, determined RECLASS from SFAS No. 115-required AFS securities footnote disclosures of AUGL, realized gains and losses, transfers of securities between the standard's three categories (trading, AFS, and held-to-maturity), and OTT impairment write-downs.
} 
with the high liquidity of most AFS securities, particularly during our largely favorable 1998-2006 sample period. It also cannot, by itself, explain why we find that the coefficients on RECLASS are well in excess of one, the normal coefficient on a perfectly measured but transitory item. Directly contradicting this possibility, we find that the coefficients on RECLASS in both the market value and returns models are more positive for banks that hold more liquid securities.

Fourth, we consider the possibility that RECLASS helps investors predict future bank performance. Unlike the unreliable fair value measurement possibility, this might explain why we find that the coefficients on RECLASS are well in excess of one. For example, if RECLASS is transitory but offsets other transitory income and thereby makes reported net income (more) permanent, then in a pricing model that includes pre-managed income, the coefficient on RECLASS will be that for a (more) permanent income item.

We provide three findings consistent with the pricing implications of RECLASS being attributable in significant part to it helping investors predict future bank performance:

- Coefficients on RECLASS in the market value and returns models are more positive for banks with higher growth in net interest income, for which predicting future performance is a more important and difficult task.

- RECLASS is significantly positively associated with year-ahead comprehensive income and two of its components-year-ahead NIBEX ${ }^{\text {other }}$ and RECLASScontrolling for current AUGL and the other components of book value and comprehensive income. These effects are stronger for banks that have higher growth.

- Including the components of year-ahead comprehensive income in the market value and returns models significantly reduces the coefficients on RECLASS for firms with higher growth. ${ }^{7}$

To the best of our knowledge, our paper is the first to document the pricing implications of reclassifications of any component of AOCI, ${ }^{8}$ thereby addressing Rees and Shane's (2012) call for research on recycling. Our results significantly update and expand upon prior research on the pricing implications of banks' realized and unrealized gains and losses by Barth (1994), who finds that realized gains do not

\footnotetext{
7 Consistent with evidence of functional fixation on earnings and other forms of mispricing in the literature (e.g., Lakonishok et al. 1994; Sloan 1996; Teohe et al. 1998; and Penman and Zhang 2002), we also considered the possibility that investors undervalue periodic unrealized gains and losses (UGL). We regressed returns for the 12 months beginning five months after fiscal year-end on UGL, Fama and French's $(1992,1993)$ three factors, and stock return momentum (Jegadeesh and Titman 1993). We found statistically weak (at the $10 \%$ level) evidence that banks with higher unrealized gains and losses experience economically modest higher future excess returns $(0.5 \%$ higher for the highest versus lowest deciles of UGL). Including the year-ahead change in RECLASS in the regression model weakened the drift and rendered it statistically insignificant, consistent with investors mispricing unrealized gains and losses in part because they do not fully incorporate their association with future RECLASS. Given the statistically weak and economically modest return drift, we concluded that investor mispricing explains at most a small portion of the high pricing implications of RECLASS.

${ }^{8}$ Badertscher et al. (2012) examine the pricing implications of banks' OTT impairments, which may but need not involve reclassifications of AOCI, depending on the extent to which the deteriorations of value captured in these impairments develop prior to the reporting quarter. We discuss this extent in Sect. 2.
} 
explain market value or returns, and Ahmed and Takeda (1995), who find that realized gains and losses explain returns only after controlling for the joint effect of interest rate exposure and interest rate movements during the period. Our primary contribution to these papers is to provide evidence that RECLASS's pricing implications obtain in significant part from it helping investors predict future bank performance.

Our results have implications for the debate about the relative and incremental usefulness of fair value versus amortized cost accounting for financial instruments. Our findings collectively support the FASB's view expressed in the May 2010 exposure draft that preserving amortized cost information based on the realization principle within a fair-value-accounting framework is useful to investors. This support is subject to two caveats, however. First, we document associations between RECLASS and market value, returns, and year-ahead comprehensive income, not that investors rely directly on RECLASS or that compensating mechanisms would not arise were RECLASS not required to be reported. Second, while we provide evidence that RECLASS facilitates investors' prediction of future bank performance by statistically reliably offsetting transitory bank income, this income smoothing does not appear to be large in magnitude or to significantly affect the market pricing of our (imperfect) measure of pre-smoothed income, NIBEX ${ }^{\text {other }}$.

The remainder of the paper is organized as follows. Section 2 summarizes relevant prior research. Section 3 develops our hypotheses and describes our research design. Section 4 describes the sample and data sources and provides descriptive statistics of the variables. Section 5 contains the analysis of the pricing implications of RECLASS. Section 6 examines the potential explanations for these pricing implications. Section 7 concludes.

\section{Prior research}

Our study is primarily related to two areas of prior research: (1) studies on the incremental and relative pricing implications of the amortized costs and fair values of banks' financial instruments, of which there are several distinct subareas, and (2) studies on the incremental and relative pricing implications of comprehensive income versus net income. We discuss these literatures in turn.

\subsection{Pricing implications of amortized costs and fair values of banks' financial instruments}

\subsubsection{Gains and losses on investment securities}

Barth (1994) and Ahmed and Takeda (1995) examine the pricing implications of disclosures of unrealized and realized gains and losses on banks' investment securities. ${ }^{9}$ Barth estimates market value and (raw) returns models in annual cross-

\footnotetext{
9 Barth (1994) hand collected the fair values of marketable securities for a sample of banks from 1970 to 1990 that appear to have disclosed the fair values of marketable securities in financial reports under industry GAAP or practice. Ahmed and Takeda (1995) obtained similar data from commercial bank holding companies' regulatory Y-9C filings from the second quarter of 1986 to the fourth quarter of 1991.
} 
sectional regressions and in pooled regressions with fixed effects. Ahmed and Takeda estimate (raw) returns models in pooled regressions.

Barth's market value model regresses market value on book value and the fair value and amortized cost of marketable securities. Estimation of this model yields a significantly positive coefficient on the fair value of marketable securities and an insignificant or significantly negative coefficient on the amortized cost of marketable securities. Barth concludes that the fair values of marketable securities provide significant explanatory power beyond amortized costs but not vice versa. Barth's returns model regresses returns on the level or change in net income before securities gains and losses, periodic realized gains and losses, and periodic total (realized plus unrealized) gains and losses. Estimation of this model yields a negative coefficient on realized gains and losses and a positive coefficient on total gains and losses that usually is insignificant except for large banks holding liquid securities. Barth interprets the weaker results in the returns model as attributable to greater noise in these income statement variables.

Ahmed and Takeda (1995) argue that the weakness of Barth's (1994) returns models results is attributable in part to omitted changes in the value of other net assets resulting from interest rate movements during the year. After controlling for the joint effect of the bank's exposure to interest rates and the change in interest rates during the year, Ahmed and Takeda find significant increases in the pricing implications of both unrealized and realized gains and losses in their returns model. $^{10}$

We modify and extend Barth (1994) and Ahmed and Takeda's (1995) analyses and findings in two primary ways. First, we find considerably stronger pricing implications for realized gains and losses than do either of these studies, particularly Barth who finds no pricing implications, but also Ahmed and Takeda who report a coefficient on realized gains and losses of 0.71 , only $12 \%$ of the 6.01 coefficient on RECLASS that we report in the returns model analysis reported in Table 3, Panel B. We believe that these stronger pricing implications obtain in part because these prior studies examine sample periods in which both realized and unrealized gains and losses on AFS securities were not prominently disclosed in financial reports and thus were less salient to users of financial reports. Specifically, the sample periods in both studies precede the issuance of any FASB fair value accounting or disclosure standard (i.e., pre-SFAS No. 107). Investors likely had not yet become comfortable using fair value information.

Since the effective date of SFAS No. 115 in 1993, AFS securities have been recognized at fair value on the balance sheet with standardized tabular format disclosures of AUGL and disclosures of realized gains and losses by type of investment security required in footnotes. Since the effective date of SFAS No. 130 in 1998, RECLASS has been prominently recognized in financial statements. Hence, for almost two decades, investors have been provided with visible information about fair values and related unrealized and realized gains and losses for AFS securities in financial reports. This presumably constitutes sufficient time

\footnotetext{
10 Ahmed and Takeda (1995) also examine the effects of income, capital, and tax management on the pricing implications of unrealized and realized gains and losses.
} 
for them to have become accustomed to and learned how to use this information. Moreover, as discussed below, prior research provides strong evidence that SFAS No. 130 increased the pricing implications of (the components of) comprehensive income.

Second, we provide evidence that RECLASS's high pricing implications are attributable in significant part to it helping investors predict future bank performance. We believe we observe these results obtain in part because banks changed considerably from the 1972-1990 period examined by Barth (1994) and the second quarter 1986 through fourth quarter 1991 period examined by Ahmed and Takeda (1995) to our 1998-2006 sample period. In these prior periods, many banks experienced poor economic performance and economic undercapitalization, problems that ultimately led to the thrift crisis toward the ends of these periods. Banks also held much longer duration assets than liabilities and faced considerable interest rate volatility, yielding high interest rate risk. For these reasons, banks' primary incentive to realize gains and losses during this period was to increase their regulatory capital, not to smooth their income. In fact, Ahmed and Takeda provide evidence that banks realized gains to increase capital during their sample period.

In contrast, during our 1998-2006 sample period, banks experienced sustained high profitability and regulatory capital, and markets for investment securities generally were liquid. Moreover, the vast majority of banks have avoided significant duration mismatches since no later than 1994. This environment was more amenable to banks realizing gains and losses on AFS securities to smooth income toward expected future income.

\subsubsection{Other-than-temporary impairments of investment securities}

Badertscher et al. (2012) examine the pricing implications of banks' OTT impairments of investment securities under the recently issued FSP FAS 115-2 and 124-2. This FSP amended FAS 115 to include only the component of the decline in fair value of investment securities attributable to declines in cash flows in OTT impairments and thus in net income. This component is included in RECLASS, our focus, to the extent that it reflects AOCI at the beginning of the reporting quarter rather than losses occurring during the quarter.

Our analysis and results overlap with those of Badertscher et al. (2012) in three limited respects. First, only 11 observations of nonzero RECLASS during our economically favorable 1998-2006 sample period result in part or whole from OTT impairments, i.e., slightly more than one per year. In contrast, Badertscher et al.'s economically unfavorable 2008-2009 sample during the crisis includes at least 239 quarterly OTT impairments by banks (at least one quarter of their 958 observations, as reported in their Table 3), i.e., 30 per quarter.

Second, OTT impairments during Badertscher et al.'s (2012) sample period likely include substantial portions that are not reclassifications of AOCI as well as portions that are reclassifications of AOCI. For example, Badertscher et al. state that "OTTI charges did not become large until September 2008," a period of economic free fall. OTT impairments recorded in such sharply deteriorating economic conditions likely include sizeable losses occurring during the reporting quarter. 
Third, Badertscher et al. (2012) find that the component of OTT impairments recorded in net income have higher pricing implications than the component of the decline in fair value attributable to increases in discount rates, which remains in AOCI after the OTT impairment under the FSP. To the extent that the cash flow component of a decline in fair value is closer to a realized loss than is the discount rate component of that decline, Badertscher et al.'s results are consistent with ours.

\subsubsection{All financial instruments}

Advocates of fair value accounting generally claim that the fair values of financial instruments are more relevant to investors than are the amortized costs of the instruments. Numerous empirical studies provide some support for this claim. These studies often, but not always, find that market values are significantly incrementally associated with fair values controlling for amortized costs, but not vice versa. The results of the studies depend on the type and liquidity of the financial instruments considered and the type of firms involved as well as aspects of the research design such as the use of market value versus returns models and inclusion of control variables. We describe only the three earliest and most influential studies below, all of which examine samples of banks.

Using disclosed fair values under SFAS No. 107, Disclosures about Fair Values of Financial Instruments, Barth et al. (1996), Nelson (1996), and Eccher et al. (1996) examine the incremental pricing implications of the differences between the disclosed fair values and reported carrying values (typically amortized costs) of essentially all banks' financial instruments, including securities, loans, deposits, and debt. The results of the three studies differ somewhat due to their differing model specifications. This is particularly true for loans, banks' most important asset, for which only Barth et al. find the differences between fair value and amortized cost to have incremental pricing implications.

Overall, the results of these studies suggest that banks' reported fair values have incremental pricing implications but also exhibit some degree of measurement unreliability depending on the instrument involved and other contextual factors. Thus these studies leave open the possibility that realizations of previously reported unrealized gains and losses can also be incrementally informative to investors.

\subsection{Comprehensive income}

Studies investigating the pricing implications of comprehensive income generally find that these implications strengthened after the effective date of SFAS No. 130, consistent with investors responding more to amounts that are recognized in financial statements rather than disclosed in footnotes. For a sample prior to the effective date of SFAS No. 130, Dhaliwal et al. (1999) find that the association of returns with comprehensive income is stronger than the association of returns with net income, except for financial firms. They also find that the AFS securities adjustment is the only component of other comprehensive income that improves the association of returns with income, again primarily for financial firms. O'Hanlon 
and Pope (1999) report similarly negative results for other comprehensive income items for a sample of UK firms.

In contrast, for samples after the effective date of SFAS No. 130, Biddle and Choi (2006) find that comprehensive income dominates other income measures in explaining equity returns. Chambers et al. (2007) find that the association between returns and the components of other comprehensive income is approximately dollar-for-dollar for the non-AFS security components (e.g., cash flow hedges and pensions) and considerably more than dollar-for-dollar (3.45, with a $t$ statistic of 4.12 on the difference from 1$)$ for the AFS security component. Chambers et al. unsuccessfully attempt to explain this higher-than-expected association by controlling for interest rate changes (which drive changes in the value of many of banks' other financial instruments) and net debt (a proxy for the extent of banks' asset-liability management).

Somewhat analogous to the capital markets studies just described, Bamber et al. (2010) examine managerial choices to disclose other comprehensive income in a performance statement that includes net income rather than in another allowed format. They find that managers with stronger equity incentives and lower job security are significantly less likely to report other comprehensive income in a performance statement, suggesting these managers believe the visibility of other comprehensive income is enhanced when disclosed in that format. Consistent with Bamber et al.'s results, in ASU 2011-5, Presentation of Comprehensive Income, the FASB recently required firms to disclose the components of comprehensive income in a performance statement, a requirement the board subsequently extended to reclassifications out of AOCI into net income in ASU 2013-02, Reporting of Amounts Reclassified Out of Accumulated Other Comprehensive Income. To avoid striating our limited number of observations on too many dimensions, we do not distinguish the particular format that banks use to make the required disclosures.

\section{Research design and hypothesis development}

\subsection{RECLASS and the mechanics of recycling gains and losses}

Under SFAS No. 115, firms initially record after-tax unrealized gains and losses on AFS securities in accumulated other comprehensive income (AOCI), a component of owners' equity. Accumulated unrealized gains and losses (AUGL) remain in AOCI until one of the following events occurs involving the securities:

(a) Sale,

(b) Transfer to trading, or

(c) Other-than-temporary (OTT) impairment write-downs.

When one of these events occurs, the related AUGL is reclassified to net income (with pretax realized gains and losses and tax effects recorded on separate line items on the income statement) and retained earnings. We refer to the after-tax reclassification as RECLASS. RECLASS changes the components but not the total amounts of owners' equity and comprehensive income. As a result, RECLASS often 
is referred to as "recycling" amounts previously recognized on the balance sheet onto the income statement.

The following equations illustrate the mechanics of this recycling. All amounts are aftertax in these equations and the remainder of the paper. Net income (NI) during a period equals net income before realized gains and losses (NIBRGL) plus RECLASS.

$$
\mathrm{NI}_{\mathrm{t}}=\mathrm{NIBRGL}_{\mathrm{t}}+\text { RECLASS }_{\mathrm{t}} \text {. }
$$

The change in retained earnings (RE) during a period equals NI minus dividends (DIV) during the period, which equals NIBRGL plus RECLASS minus DIV during the period:

$$
\Delta \mathrm{RE}_{\mathrm{t}}=\mathrm{NI}_{\mathrm{t}}-\mathrm{DIV}_{\mathrm{t}}=\mathrm{NIBRGL}_{\mathrm{t}}+\mathrm{RECLASS}_{\mathrm{t}}-\mathrm{DIV}_{\mathrm{t}} .
$$

Hence RE increases with RECLASS.

The change in AUGL during a period equals the unrealized gain or loss (UGL) during the period. UGL equals the total (i.e., unrealized plus realized) gain or loss (TGL) minus RECLASS during the period.

$$
\Delta \mathrm{AUGL}_{\mathrm{t}}=\mathrm{UGL}_{\mathrm{t}}=\mathrm{TGL}_{\mathrm{t}}-\mathrm{RECLASS}_{\mathrm{t}}
$$

Hence AUGL decreases with RECLASS.

The change in owners' equity (OE) equals $\triangle \mathrm{RE}$ plus $\triangle \mathrm{AOCI}$ plus the change in contributed capital $(\triangle \mathrm{CC})$ during the period. $\triangle \mathrm{RE}$ is given in Eq. (2) and $\triangle \mathrm{AOCI}$ equals $\triangle \mathrm{AUGL}$ plus other comprehensive income from sources other than AFS securities $\left(\mathrm{OCI}^{\text {other }}\right)$ during the period, yielding

$$
\begin{aligned}
\Delta \mathrm{OE}_{\mathrm{t}} & =\Delta \mathrm{RE}_{\mathrm{t}}+\Delta \mathrm{AOCI}_{\mathrm{t}}+\Delta \mathrm{CC}_{\mathrm{t}} \\
& =\mathrm{NIBRGL}_{\mathrm{t}}+\mathrm{RECLASS}_{\mathrm{t}}-\mathrm{DIV}_{\mathrm{t}}+\mathrm{TGL}_{\mathrm{t}}-\mathrm{RECLASS}_{\mathrm{t}}+\mathrm{OCI}_{\mathrm{t}}^{\text {other }}+\Delta \mathrm{CC}_{\mathrm{t}} \\
& =\mathrm{NIBRGL}_{\mathrm{t}}+\mathrm{TGL}_{\mathrm{t}}-\mathrm{DIV}_{\mathrm{t}}+\mathrm{OCI}_{\mathrm{t}}^{\text {other }}+\Delta \mathrm{CC}_{\mathrm{t}} .
\end{aligned}
$$

Hence $\triangle \mathrm{OE}$ is unaffected by RECLASS due to its perfectly offsetting effects on RE and AOCI.

\subsection{Market value model}

Our market value model is an expanded version of the frequently estimated regression of market value on book value of equity, denoted $\mathrm{BV}$, and comprehensive income, denoted $\mathrm{CI}$ :

$$
\mathrm{MV}_{\mathrm{t}}=\alpha+\beta_{1} \mathrm{BV}_{\mathrm{t}}+\beta_{2} \mathrm{CI}_{\mathrm{t}}+\varepsilon_{\mathrm{t}} .
$$

Ohlson (1995) derives a model similar to Eq. (5) from three assumptions: (1) dividend discounting with a constant cost of equity r, (2) clean surplus accounting, and (3) a first-order autoregressive process for abnormal comprehensive income. ${ }^{11}$ Ohlson shows that perfectly transitory (e.g., fair value accounting-based) abnormal

\footnotetext{
11 Equation (7) in Ohlson (1995) differs in four primary respects from our Eq. (5). First, Ohlson's comprehensive income term is a capitalization of comprehensive income reduced by dividends. Second, the weights on the book value and income terms are inversely related. Third, he allows for nonaccounting information. Fourth, his equation does not include an intercept.
} 
comprehensive income yields a pure balance sheet model with $\beta_{1}=1$ and $\beta_{2}=0$. He shows that perfectly permanent abnormal comprehensive income yields a pure income statement model with $\beta_{1}=0$ and, assuming a constant rate of dividend payout of comprehensive income $\lambda, \beta_{2}=(1+\mathrm{r}) / \mathrm{r}-\lambda^{12}$

We decompose both BV and CI into components in fashions consistent with but somewhat more detailed than Eqs. (1)-(4). Specifically, we decompose BV into the after-tax book value of AFS securities $\left(\mathrm{BV}^{\text {afs }}\right)$ plus the after-tax book value of other net assets $\left(\mathrm{BV}^{\text {other }}\right)$. We further decompose $\mathrm{BV}^{\text {afs }}$ into the amortized cost of AFS securities (COST) plus AUGL. We decompose CI into RECLASS, NIBEX ${ }^{\text {other }}$, EX, and other comprehensive income (OCI). We further decompose OCI into $\triangle$ AUGL (which equals TGL-RECLASS or equivalently UGL) and $\mathrm{OCI}^{\text {other }}$. Incorporating these variable decompositions into Eq. (5) yields the market value model:

$$
\begin{aligned}
\mathrm{MV}_{\mathrm{t}}= & \alpha+\beta_{1} \mathrm{COST}_{\mathrm{t}}+\beta_{2} \mathrm{AUGL}_{\mathrm{t}}+\beta_{3} \mathrm{BV}_{\mathrm{t}}^{\text {other }}+\beta_{4} \text { RECLASS }_{\mathrm{t}}+\beta_{5} \text { NIBEX }_{\mathrm{t}}^{\text {other }} \\
& +\beta_{6} \mathrm{EX}_{\mathrm{t}}+\beta_{7} \Delta \mathrm{AUGL}_{\mathrm{t}}+\beta_{8} \mathrm{OCI}_{\mathrm{t}}^{\text {other }}+\varepsilon_{\mathrm{t}}
\end{aligned}
$$

We also estimate nested versions of Eq. (6) that include only the balance sheet variables COST, AUGL, and $\mathrm{BV}^{\text {other }}$ or only the comprehensive income statement variables RECLASS, NIBEX ${ }^{\text {other }}$, EX, $\triangle$ AUGL, and $\mathrm{OCI}^{\text {other }}$.

\subsection{Returns model}

Because market value models such as Eq. (6) are susceptible to scale-related specification problems, we also estimate a returns model (Easton and Sommers 2003). The trade-off is that the first-differenced explanatory variables in returns models generally are noisier, as discussed by Barth (1994). We estimate a returns model that is simpler than Eq. (6) to avoid exacerbating the effects of this noise through over-differenced or multicollinear explanatory variables.

Our returns model is motivated by Badertscher et al. (2012), who regress marketadjusted returns on the changes in the relatively permanent components of comprehensive income and the levels of the relatively transitory components of comprehensive income. In Eq. (6), the only relatively permanent component of comprehensive income is $\mathrm{NIBEX}^{\text {other }}$ and the relatively transitory components are RECLASS, EX, $\triangle$ AUGL, and OCI ${ }^{\text {other }}$. Applying Badertscher et al.'s approach to these comprehensive income variables and denoting market-adjusted returns for the 12-month period ending at the end of the fourth month after the firm's fiscal year end by $\mathrm{R}_{\mathrm{t}}$, yields the returns model:

$\mathrm{R}_{\mathrm{t}}=\mathrm{a}+\mathrm{b}_{1}$ RECLASS $_{\mathrm{t}}+\mathrm{b}_{2} \Delta$ NIBEX $_{\mathrm{t}}^{\text {other }}+\mathrm{b}_{3} \mathrm{EX}_{\mathrm{t}}+\mathrm{b}_{4} \Delta \mathrm{AUGL}_{\mathrm{t}}+\mathrm{b}_{5} \mathrm{OCI}_{\mathrm{t}}^{\text {other }}+\mathrm{e}_{\mathrm{t}}$.

Consistent with the specification of $R_{t}$, the explanatory variables in Eq. (7) are deflated by beginning-of-return-interval market capitalization.

\footnotetext{
12 If dividend payout is not constant, then dividends should be incorporated in Ohlson's (1995) capitalized comprehensive income term. However, prior research by Hand and Landsman (1998) finds that including dividends in the Ohlson model empirically appears to capture dividends signaling future income rather than dividend payout.
} 
While Eq. (7) yields slightly better goodness of fit than a model that includes the changes rather than levels in the relatively transitory components of comprehensive income, our results and related interpretations are not qualitatively affected by this choice. It is important that RECLASS and $\triangle$ AUGL are treated the same way, however, to maintain the algebraic relationship between these variables in Eq. (3).

In untabulated robustness tests for Eqs. (6) and (7), we include a large number of control variables motivated by Ahmed and Takeda (1995)—in particular, their interactive interest rate exposure/interest rate change variable-and the broader banking literature. We also further decompose the explanatory variables by line item. These robustness tests yield the same inferences as the tests reported in the paper. Ahmed and Takeda's interactive interest rate variable is insignificant in all models, apparently due to banks' considerably reduced interest rate exposure and the lower interest rate volatility during our sample period compared to their prior sample period.

We develop five pairs of null and alternative hypotheses that investigate the extent and determinants of the pricing implications of RECLASS.

\subsection{Pricing implications hypotheses}

The first pair of hypotheses pertains to whether RECLASS has pricing implications incremental to $(\Delta)$ AUGL and the other explanatory variables in Eqs. (6) and (7). The null hypothesis is that RECLASS has no incremental pricing implications, because $(\Delta)$ AUGL and the other control variables convey all relevant information. The alternative hypothesis is that RECLASS has positive incremental pricing implications due to the importance of realization.

In Eqs. (6) and (7), RECLASS appears both directly as a separate variable (its effect on NI) as indirectly as a decrease in $\triangle \mathrm{AUGL}_{\mathrm{t}}$ (its effect on OCI). While this double inclusion of RECLASS in the empirical models may appear complex, it results from the offsetting effects of reclassifications of AOCI into net income associated with recycling and so cannot be eliminated from the models without either suppressing recycling (i.e., RECLASS has offsetting effects on net income and other comprehensive income but no effects on comprehensive income) or losing the models' underlying structure attributable to Ohlson (1995) or Badertscher et al. (2012). Hence we state this and subsequent hypotheses as restrictions on the "total" coefficients on RECLASS. The total coefficient is $\beta_{4}-\beta_{7}$ in the market value model Eq. (6) and $b_{1}-b_{4}$ in the returns model Eq. (7). ${ }^{13}$

\footnotetext{
13 RECLASS also affects AUGL and, depending on the type of realization of gains and losses, one of COST or BV $\mathrm{BV}^{\text {other }}$ in Eq. (6) [This issue does not arise in Eq. (7)]. For example, for economic realizations of gains, RECLASS also appears as an increase in $\mathrm{BV}^{\text {other }}$ (its effect on cash) and a decrease in AUGL (its effect on AFS securities). However, unlike RECLASS's direct and indirect effects discussed in the text, these two additional effects would exist in a clean surplus fair value accounting system that does not report RECLASS or otherwise preserve amortized cost information about realized gains and losses. We conduct our tests using the total coefficient $\beta_{4}-\beta_{7}$ because it better corresponds to our focus. However, we have also conducted all tests using the alternative total coefficient $\left(\beta_{3}+\beta_{4}\right)-\left(\beta_{2}+\beta_{7}\right)$, which yields the same conclusions as for our tests using $\beta_{4}-\beta_{7}$, albeit with slightly lower significance levels (e.g., $5 \%$ instead of $1 \%$ in our primary tests reported in column III of Table 3, Panel A).
} 
H1N: $\quad \beta_{4}-\beta_{7}=0$ in the market value model $\left(b_{1}-b_{4}=0\right.$ in the returns model $)$.

H1A: $\quad \beta_{4}-\beta_{7}>0$ in the market value model $\left(b_{1}-b_{4}>0\right.$ in the returns model). ${ }^{14}$

For brevity, we combine the hypotheses for the market value and returns models in this and the following hypotheses.

If banks use RECLASS to offset variation in NIBEX ${ }^{\text {other }}$, thereby enabling investors to better predict future NIBEX ${ }^{\text {other }}$, the inclusion of RECLASS in the empirical models should also increase the coefficients on $(\Delta) \mathrm{NIBEX}^{\text {other }}$ in the market value (returns) models. We do not make hypotheses about the effect of the inclusion of RECLASS on these coefficients, because we do not know whether banks use RECLASS to smooth NIBEX ${ }^{\text {other }}$ versus other income variables, whether the income variable smoothed varies across banks or time, or the amount of the noise in any income smoothing using RECLASS, given that banks have various other income smoothing mechanisms (see footnote 5). However, we do report and discuss the effect of the inclusion of RECLASS on these coefficients.

\subsection{Unreliable fair value measurement hypotheses}

Our second pair of hypotheses examines whether RECLASS's pricing implications are attributable to the unreliability of reported fair values, as critics of fair value accounting often allege. To the extent that this allegation is true and RECLASS remedies the unreliability of reported fair values, RECLASS's pricing implications should be more positive for banks that hold less liquid securities for which fair values likely are measured less reliably:

H2N: $\quad \beta_{4}-\beta_{7}$ in the market value model $\left(b_{1}-b_{4}\right.$ in the returns model) does not vary with the liquidity of banks' AFS securities.

H2A: $\quad \beta_{4}-\beta_{7}$ in the market value model $\left(b_{1}-b_{4}\right.$ in the returns model $)$ is more positive for banks holding less liquid AFS securities.

As discussed in Sect. 2, while hypothesis H2A has some attractiveness and is consistent with Barth's (1994) results, there are also several strong reasons to believe it will not hold during our sample period.

\subsection{Predicting future bank performance hypotheses}

Our remaining hypotheses examine the possibility that RECLASS's pricing implications result from it helping investors predict future bank performance, a

\footnotetext{
14 We do not consider the effect of taxes on the total coefficient on RECLASS (an aftertax variable). Warfield and Linsmeier (1992) examine the effect of cross-sectional differences in taxes on the coefficient on realized gains and losses. They argue and provide evidence that realized losses for taxpaying firms and realized gains for nontax-paying firms convey good news, at least for the first three quarters of the fiscal year. In principle, these differences could affect the coefficients on RECLASS in our empirical models. Due to the almost universal good health of the banking industry during our sample period-far better than the 1980-1985 period examined by Warfield and Linsmeier-our sample banks invariably paid taxes.
} 
more important and difficult task for higher growth banks. This would occur if banks realize gains and losses on AFS securities to smooth their reported net income towards management's expectations of future income, as discussed by Barnea et al. (1976), Ronen and Sadan (1981), and Ronen (2008). ${ }^{15}$ Banks have considerable ability to smooth income in this fashion, because they actively use AFS securities in asset-liability management, and so gains (losses) on these securities are likely to be economically offset by losses (gains) on other positions they hold. We provide descriptive evidence that RECLASS smoothes income in Sect. 4.

Unlike the unreliable fair value measurement possibility, this possibility can yield a coefficient above one on RECLASS. This point is obvious if RECLASS is permanent, but it also holds, for example, if RECLASS is transitory but offsets other transitory income and thereby makes reported net income (more) permanent. In that case, in a pricing model that includes pre-managed income, the coefficient on RECLASS will be that for a (more) permanent income item.

To demonstrate this point simply, assume price equals a constant perpetuity factor times permanent income and that pre-managed income equals permanent income plus an uncorrelated transitory item. If a managed income item perfectly offsets that transitory item, then price equals the perpetuity factor times premanaged income plus the offsetting managed item, i.e., the coefficient on the managed item would be the perpetuity factor. (Moreover, if the managed item perfectly offsets a fixed proportion less than $100 \%$ of the transitory item, then the coefficient on the managed item would be above the perpetuity factor.) It is straightforward, although tedious depending on the assumptions made, to show this point holds under more general assumptions.

The next pair of hypotheses examines whether RECLASS has stronger pricing implications for higher growth banks for which predicting future bank performance is more important and difficult.

H3N: $\quad \beta_{4}-\beta_{7}$ in the market value model $\left(b_{1}-b_{4}\right.$ in the returns model $)$ does not vary with banks' growth.

H3A: $\quad \beta_{4}-\beta_{7}$ in the market value model $\left(b_{1}-b_{4}\right.$ in the returns model) is more positive for higher growth banks.

To directly test whether RECLASS's pricing implications result from it helping investors to predict future income, we regress year-ahead CI on the same explanatory variables in Eq. (6).

$$
\begin{aligned}
\mathrm{CI}_{\mathrm{t}+1}= & \delta+\gamma_{1} \mathrm{COST}_{\mathrm{t}}^{\mathrm{afs}}+\gamma_{2} \mathrm{AUGL}_{\mathrm{t}}+\gamma_{3} \mathrm{BV}_{\mathrm{t}}^{\text {other }}+\gamma_{4} \text { RECLASS }_{\mathrm{t}}+\gamma_{5} \text { NIBEX }_{\mathrm{t}}^{\text {other }} \\
& +\gamma_{6} \mathrm{EX}_{\mathrm{t}}+\gamma_{7} \Delta \mathrm{AUGL}_{\mathrm{t}}+\gamma_{8} \mathrm{OCI}_{\mathrm{t}}^{\text {other }}+\eta_{\mathrm{t}} .
\end{aligned}
$$

We also estimate Eq. (8) with two components of $\mathrm{CI}_{\mathbf{t}+1}$ as the dependent variable, NIBEX $_{\mathrm{t}+1}^{\mathrm{other}}$, and RECLASS $\mathrm{t}_{\mathrm{t}+1}$. Regardless of the dependent variable, the null and alternative hypotheses pertain to the total coefficient on RECLASS in Eq. (8),

\footnotetext{
15 We do not investigate whether realization of gains and losses smooths net income in a fashion deemed credible by investors. We note, however, that costs that might yield such credibility include regulatory costs associated with realization of losses, tax costs associated with realization of gains, and reputational consequences for managers who manage income along an ex post unsmooth path.
} 
$\gamma_{4}-\gamma_{7}$. Under the alternative hypothesis, we expect this total coefficient to be positive when the pricing implications of RECLASS are positive.

H4N: $\quad \gamma_{4}-\gamma_{7}=0$ for samples for which $\beta_{4}-\beta_{7}>0$ in the market value model $\left(b_{1}-b_{4}>0\right.$ in the returns model).

H4A: $\quad \gamma_{4}-\gamma_{7}>0$ for samples for which $\beta_{4}-\beta_{7}>0$ in the market value model $\left(b_{1}-b_{4}>0\right.$ in the returns model).

In testing hypothesis $\mathrm{H} 4$, we focus on the growth subsamples across which we expect, based on the results of testing hypothesis H3, RECLASS's predictive power for future bank performance to vary the most.

To test directly whether RECLASS's pricing implications stem from its predictive power over future comprehensive income, we add the components of year-ahead comprehensive income to Eqs. (6) and (7) in exactly the same forms that the components of current comprehensive income appear in the models. For brevity, we do not reproduce these models with the additional variables. We denote the coefficients in these expanded models with primes. We hypothesize that the total coefficients on RECLASS for the current year decrease with the inclusion of the components of year-ahead comprehensive income.

$\mathrm{H} 5 \mathrm{~N}: \quad \mathrm{B}_{4}^{\prime}-\beta_{7}^{\prime}=\beta_{4}-\beta_{7}$ in the market value model $\left(\mathrm{b}^{\prime}{ }_{1}-\mathrm{b}_{4}^{\prime}=\mathrm{b}_{1}-\mathrm{b}_{4}\right.$ in the returns model).

H5A: $\quad \mathrm{B}_{4}^{\prime}-\beta_{7}^{\prime}<\beta_{4}-\beta_{7}$ in the market value model $\left(\mathrm{b}^{\prime}{ }_{1}-\mathrm{b}_{4}^{\prime}<\mathrm{b}_{1}-\mathrm{b}_{4}\right.$ in the returns model).

In testing hypothesis H5, we focus on the high growth subsample for which we expect, based on the results of testing hypotheses H3 and H4, RECLASS's predictive power for future bank performance to have the largest effect on RECLASS's pricing implications.

\section{Sample, data, and descriptive statistics}

We obtain most accounting and market value data from Compustat and stock return data from CRSP. We hand collected AUGL and RECLASS from disclosures of the components of (accumulated) other comprehensive income in banks' annual reports. In the "Appendix", we provide several examples of these disclosures.

SFAS No. 130 requires firms to prominently report other comprehensive income and its components in financial statements for fiscal years beginning after December 15, 1997. For this reason, our sample period begins in 1998, and it covers the nine fiscal years through 2006. Because of the time required to hand collect AUGL and RECLASS, we restrict our sample to the 200 largest US commercial banks based on total assets in 1998. We also require the sample banks to be traded on NYSE, AMEX, or NASDAQ and to have all necessary data on the variables in Eq. (6). The market capitalization of the 200 banks ranges from $\$ 50$ million to $\$ 230$ billion, indicating that our sample selection based on size is not particularly restrictive. Our 
final sample contains 1,033 bank-year observations with complete data on the Eq. (6) variables.

Recall that RECLASS results from three different events: sales of AFS securities, transfer of the securities to trading, and OTT impairment write-downs of the securities. The first event involves economic realization, and the second and third events involve realization for accounting purposes only. Analysis of our handcollected disclosures indicates that only 11 of the sample observations had reclassifications that were due in part or whole to AFS securities being transferred to trading or other-than-temporary impairment write-downs, i.e., realization for accounting purposes only. ${ }^{16}$ The low frequency of transfers to trading likely results from the proviso in paragraph 15 of SFAS No. 115 that such transfers should be "rare." The low frequency of OTT impairment write-downs likely results from our sample period preceding the financial crisis and the fact that firms generally do not record impairments for declines in value driven by movements in interest rates unless they have decided to sell the affected securities. Hence almost all of the variation in RECLASS reflects sales of securities, i.e., economic realization.

Table 1 Panel A reports descriptive statistics for the explanatory variables in Eqs. (6) and (7) as well as other variables. The mean of AUGL is 8 cents per share, with a sizeable standard deviation of 68 cents per share. AUGL likely is positive on average because interest rates decreased significantly and fairly steadily for almost two decades prior to our sample period. Equity prices also rose considerably, albeit less steadily, over this period.

The mean of RECLASS is 3 cents per share, with a standard deviation of 16 cents per share. The mean ratio of the absolute value of RECLASS to the absolute value of NIBEX $^{\text {other }}$ is $5 \%$, with a standard deviation of $20 \%$, indicating that the realization of gains and losses on AFS securities typically has a sizeable effect on net income, although by no means does RECLASS offset all of the variation in NIBEX $^{\text {other }}$. The mean of TGL is negative 2 cents per share, with a standard deviation of 57 cents per share. The opposite signs of mean TGL and mean RECLASS indicate a disconnect exists between total and realized gains and losses. The standard deviation of TGL is about three and a half times larger than the standard deviation of RECLASS, illustrating that total gains and losses are far more variable than are realized gains and losses.

Table 1 Panel B1 (Panel B2) reports correlations of the explanatory variables in Eq. (6) [Eq. (7)]. Pearson (Spearman) correlations are reported above (below) the diagonals. In Panel B1, RECLASS has a significant positive correlation with AUGL of 0.20 Pearson and 0.27 Spearman, consistent with banks realizing gains and losses in a fashion that reflects unrealized gains and losses available to be realized to some degree. RECLASS has a significant negative correlation with NIBEX $^{\text {other }}$ of -0.10 , both Pearson and Spearman, consistent with banks using RECLASS to smooth net income. In Panel B2, RECLASS has a significant negative Spearman correlation

\footnotetext{
16 Possibly this low frequency reflects nondisclosure by banks of immaterial realizations for accounting purposes only, given that SFAS No. 115's provisions need not be applied to immaterial items. Partly for this reason, we do not remove these 11 observations from the sample. Our results are not noticeably affected by the removal of these observations from the sample.
} 
Table 1 Descriptive statistics

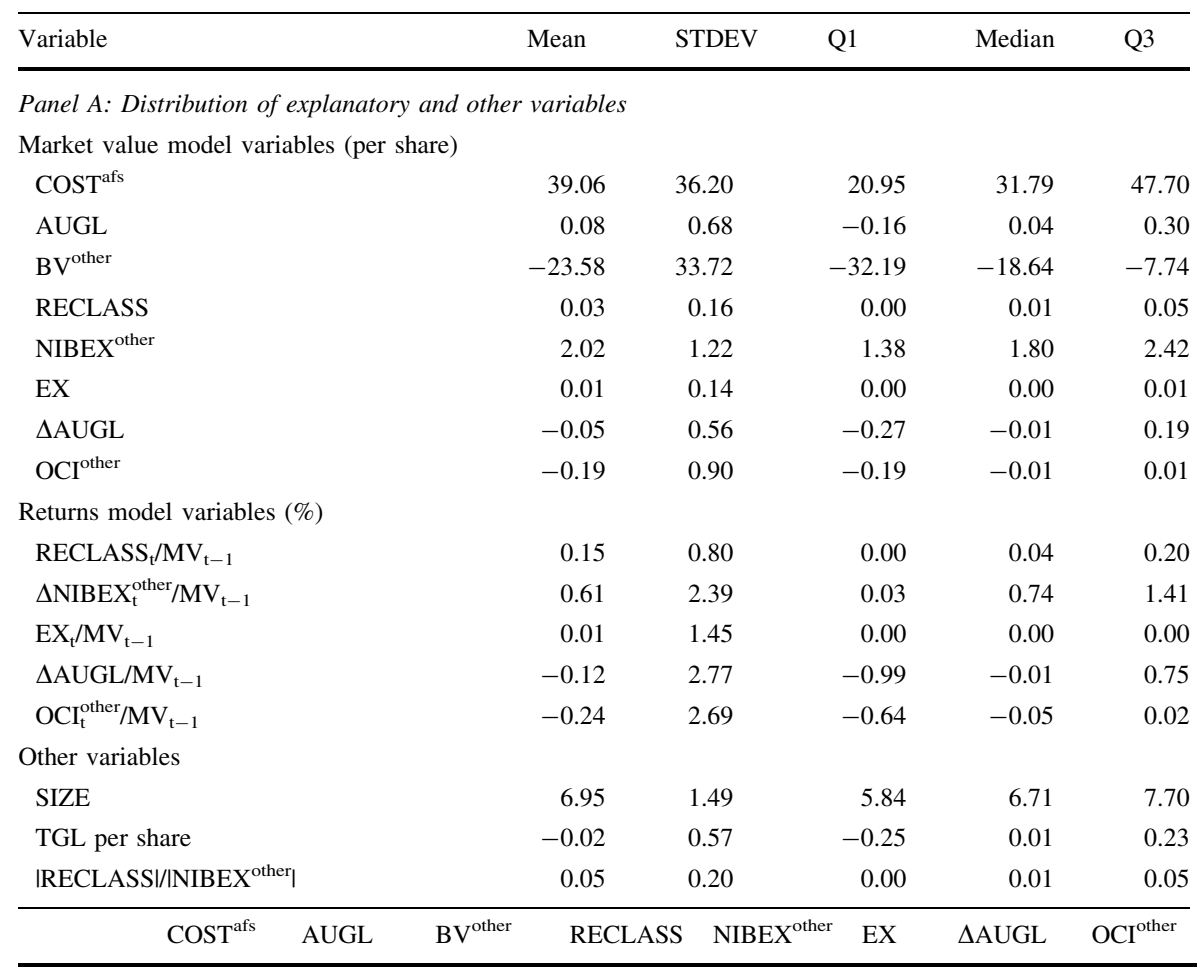

Panel B1: Correlations of market value model variables (per share) (pearson above diagonal and spearman below diagonal)

\begin{tabular}{|c|c|c|c|c|c|c|c|c|}
\hline $\operatorname{cosT}^{\mathrm{afs}}$ & & -0.05 & $-0.96 * * *$ & 0.01 & $0.33 * * *$ & 0.01 & $-0.09 * * *$ & 0.02 \\
\hline AUGL & $0.07 * *$ & & $0.08 * *$ & $0.20 * * *$ & $0.14 * * *$ & -0.00 & $0.49 * * *$ & $-0.15^{* * *}$ \\
\hline $\mathrm{BV}^{\text {other }}$ & $-0.94 * * *$ & $-0.07 * *$ & & -0.03 & $-0.12^{* * *}$ & -0.00 & $0.09 * *$ & -0.02 \\
\hline RECLASS & $0.06^{*}$ & $0.27 * * *$ & $-0.09 * * *$ & & $-0.10^{* * *}$ & 0.01 & $-0.11 * * *$ & $-0.18^{* *}$ \\
\hline NIBEX $^{\text {other }}$ & $0.40 * * *$ & $0.08^{* * *} *$ & $-0.18^{* * *}$ & $-0.10^{* * *}$ & & 0.02 & 0.01 & $-0.05^{*}$ \\
\hline EX & 0.01 & -0.01 & 0.04 & 0.02 & $0.14 * * *$ & & 0.02 & -0.01 \\
\hline$\triangle \mathrm{AUGL}$ & -0.01 & $0.45^{* * * *}$ & 0.01 & $-0.07 * *$ & 0.01 & 0.03 & & -0.03 \\
\hline \multirow[t]{2}{*}{$\mathrm{OCI}^{\text {other }}$} & -0.04 & $-0.18^{* * *}$ & $0.06^{*}$ & $-0.25 * * *$ & $-0.06^{*}$ & -0.05 & -0.03 & \\
\hline & & RECLASS & & other & EX & $\Delta \mathrm{AU}$ & & Ither \\
\hline
\end{tabular}

Panel B2: Correlations of returns model variables (\%) (pearson above diagonal and spearman below diagonal)

\begin{tabular}{|c|c|c|c|c|c|}
\hline RECLASS $_{\mathrm{t}} / \mathrm{MV}_{\mathrm{t}-1}$ & & -0.05 & $-0.29 *$ & $-0.12 * * *$ & $0.12 * *$ \\
\hline$\Delta \mathrm{NIBEX}_{\mathrm{t}}^{\text {other }} / \mathrm{MV}_{\mathrm{t}-1}$ & $-0.14 * * *$ & & $-0.10^{* *}$ & -0.05 & 0.03 \\
\hline $\mathrm{EX}_{\mathrm{t}} / \mathrm{MV}_{\mathrm{t}-1}$ & -0.02 & $-0.07 *$ & & $-0.14 *$ & $0.31^{*}$ \\
\hline$\Delta \mathrm{AUGL}_{\mathrm{t}} / \mathrm{MV}_{\mathrm{t}-1}$ & $-0.07 *$ & -0.00 & 0.03 & & -0.05 \\
\hline
\end{tabular}


Table 1 continued

\begin{tabular}{llllll}
\hline & RECLASS & $\Delta$ NIBEX $^{\text {other }}$ & EX & $\Delta$ AUGL & OCI $^{\text {other }}$ \\
\hline OCI $_{\mathrm{t}}^{\text {other }} / \mathrm{MV}_{\mathrm{t}-1}$ & $-0.27^{* * *}$ & 0.03 & -0.04 & $-0.11^{* *}$ & \\
\hline
\end{tabular}

The sample includes the 200 largest (based on total assets in 1998) US commercial banks traded on NYSE, AMEX, and NASDAQ for the years 1998-2006. Stock return data are obtained from CRSP and most financial data are obtained from COMPUSTAT. Accumulated unrealized gains and losses on available for sale (AFS) securities (denoted AUGL) and reclassifications of AUGL upon realization of gains and losses (denoted RECLASS) are hand collected from banks' annual Form 10-K filings. Panel A reports descriptive statistics for the explanatory variables in the market value model [Eq. (6)] and returns model [Eq. (7)] as well as other variables. Panel B1 (B2) reports Pearson and Spearman correlations of the explanatory variables in the market value (returns) model. In the market value model, balance sheet variables are deflated by shares outstanding at the fiscal year-end, and comprehensive income statement variables are deflated by the shares outstanding used to calculate earnings per share. Returns model variables are deflated by the market value of equity at the end of the fourth month of the fiscal year. COST ${ }^{\text {afs }}$ denotes the amortized cost of AFS securities. BV ${ }^{\text {other }}$ denotes the net book value of assets and liabilities other than AFS securities. NIBEX ${ }^{\text {other }}$ denotes net income before extraordinary items (denoted EX) and RECLASS. OCI ${ }^{\text {other }}$ denotes other comprehensive income before the change in AUGL. SIZE denotes the natural logarithm of the market value of equity at the end of the fourth month of the fiscal year. TGL denotes total gains and losses on AFS securities. The full sample includes 1,033 observations with nonmissing AUGL, RECLASS, and TGL. *, **, and *** statistical significance at the 10, 5, and $1 \%$ levels, respectively, in two-tailed tests

with NIBEX ${ }^{\text {other }}$ of -0.14 , again consistent with income smoothing. The Pearson correlation is also negative but insignificant.

Table 2 reports descriptive analyses regressing RECLASS on current NIBEX ${ }^{\text {other }}$ by itself and also controlling for current AUGL in Panel A and controlling for TGL for the current and three prior years in Panel B. The purpose of these analyses is to provide insight into two issues: (1) whether banks use RECLASS to manage income-income smoothing would yield a negative association of RECLASS with NIBEX $^{\text {other }}$, while big baths would yield the opposite-and (2) the strength and lag structure of the relationship between realized and unrealized gains and losses.

The two panels of Table 2 provide consistent results. There is evidence of income smoothing through realization of gains and losses, with a negative coefficient of -0.01 on NIBEX $^{\text {other }}$ significant at the $5 \%$ level without any control, at the $1 \%$ level controlling for AUGL, and the $5 \%$ level controlling for current and lagged TGL. While significant, this coefficient is rather small, suggesting one or more of the following: banks' income smoothing is limited; RECLASS is not banks' primary income smoothing mechanism; or banks offset variation in a pre-managed income variable other than NIBEX ${ }^{\text {other }}$. The pricing implications of RECLASS stem primarily from the statistical reliability with which it smooths net income, however, not from the magnitude of the smoothing.

The table also provides evidence of gradual realization of gains and losses, implying that RECLASS is persistent. Panel A reports a positive coefficient of 0.04 on AUGL, significant at the $1 \%$ level. Panel B reports coefficients on current and lagged TGL that smoothly decline from 0.12 for current TGL to 0.05 for three-yearlagged TGL, with all of the coefficients significant at the $5 \%$ level or better. 
Table 2 Reclassifications, income smoothing, and gradual realization of total gains and losses

\begin{tabular}{lll}
\hline \multicolumn{3}{c}{ Dependent variable: RECLASS } \\
\hline Panel A: Using current level of accumulated unrealized gains and losses \\
Intercept & 0.02 & $0.03^{*}$ \\
NIBEX $^{\text {other }}$ & $-0.01^{* *}$ & $-0.01^{* * *}$ \\
AUGL & & $0.04^{* * *}$ \\
$\mathrm{~N}$ & 1,003 & 1,033 \\
$\mathrm{R}^{2}$ & 0.04 & 0.07 \\
\hline
\end{tabular}

Dependent variable: RECLASS

Panel B: Distinguishing timing of total gains and losses

\begin{tabular}{ll} 
Intercept & $0.07 * *$ \\
NIBEX & \\
TGL, year & $-0.01 * *$ \\
TGL, year-1 & $0.12 * * *$ \\
TGL, year-2 & $0.09 * * *$ \\
TGL, year-3 & $0.07 * *$ \\
N & $0.05 * * *$ \\
$\mathrm{R}^{2}$ & 614 \\
\hline
\end{tabular}

This table reports the results of regressing the reclassification of AUGL upon realization of gains and losses (RECLASS) on net income before extraordinary items and RECLASS (NIBEX ${ }^{\text {other }}$ ), without and with controlling for accumulated unrealized gains and losses (AUGL) for the current year (Panel A) and on NIBEX ${ }^{\text {other }}$ controlling for total gains and losses (TGL) for the current and prior three years (Panel B). AUGL is deflated by the number of shares outstanding at fiscal year-end. NIBEX ${ }^{\text {other }}$ and TGL are deflated by the number of shares used in calculating earnings per share. Year dummies are included in all regression, with $t$-statistics adjusted for clustering among observations for the same firm (Petersen 2009). $*$, **, and $* * *$ statistical significance at 10,5 , and $1 \%$ levels, respectively, in two-tailed tests

\section{Pricing implications of RECLASS}

Table 3 Panel A presents the results of estimating the market value model Eq. (6). To mitigate heteroscedasticity, we deflate book value and its components by shares outstanding at the end of the year and deflate comprehensive income and its components by average shares outstanding during the period used in the calculation of earnings per share. In untabulated robustness tests, we alternatively deflate by total assets and total revenues, which yields the same inferences. To address clustering of observations, in all equations estimated in this paper, we include year fixed effects and report $t$-statistics that incorporate clustering of observations by firm (Petersen 2009).

As benchmarks for the estimation of the full Eq. (6) reported in column V, we first discuss the estimation of four nested versions of the equation: a pure balance sheet model (column I), a pure comprehensive income statement model both without and with RECLASS (columns II and III), and a combined balance sheet and comprehensive income statement model without RECLASS (column IV). We 
maintain the same decompositions of BV and CI, respectively, in the nested models as in the full model.

The results of estimating the pure balance sheet model reported in column I indicate that MV is significantly positively associated with AUGL at the $5 \%$ level. Similar to Chambers et al.'s (2007) estimated coefficient on $\triangle$ AUGL in their returns model, the coefficient of 3.25 on AUGL is over twice as high as the coefficients on COST and $\mathrm{BV}^{\text {other; }}$ in fact, this coefficient is much higher than expected for transitory gains and losses. As discussed below, this coefficient decreases to a normal level once RECLASS and the other comprehensive income variables are added to the model. These results are consistent with investors assigning at least normal pricing implications to unrealized gains and losses.

The results of estimating the pure comprehensive income statement model with RECLASS included in column III indicate that MV is significantly positively associated with RECLASS. The total coefficient on RECLASS is $\beta_{4}-$ $\beta_{7}=9.88-0.42=9.46$, significant at the $1 \%$ level. The total coefficient is closer to the coefficient of 13.34 on the relatively permanent NIBEX $^{\text {other }}$ than it is to the coefficient on the relatively transitory comprehensive income components: 2.05 on EX, 0.42 on $\triangle \mathrm{AUGL}$, and 1.49 on $\mathrm{OCI}^{\text {other }}$. These results are consistent with investors assigning considerably greater pricing implications to realized than unrealized gains and losses. The results likely are attributable in part to RECLASS smoothing net income and being persistent, as reported in Table 2.

Comparison of the comprehensive income statement models without and with RECLASS reported in columns II and III indicate that the inclusion of RECLASS in the model raises the coefficient on NIBEX ${ }^{\text {other }}$ from 12.22 to 13.34 , as expected if RECLASS offsets variation in NIBEX ${ }^{\text {other }}$, with both coefficients significant at the $1 \%$ level. However, the difference of these coefficients is insignificant.

The results of estimating the full Eq. (6) reported in column V indicate that the pricing implications of RECLASS diminish only slightly when AUGL and the other balance sheet variables are added to the model. Specifically, the total coefficient on RECLASS is $\beta_{4}-\beta_{7}=7.84-0.56=7.28$, significant at the $1 \%$ level. This total coefficient is again closer to the coefficient of 10.84 on the relatively permanent NIBEX $^{\text {other }}$ than to the coefficients on the relatively transitory comprehensive income components: 1.82 on EX, 0.56 on $\triangle \mathrm{AUGL}$, and 1.29 on $\mathrm{OCI}^{\text {other }}$. In contrast, the coefficient on AUGL falls from 3.25 to $0.72,{ }^{17}$ below the expected coefficient of one for transitory gains and losses, and becomes insignificant when RECLASS and the other comprehensive income statement variables are added to the model.

Comparison of the full models without and with RECLASS reported in columns IV and V indicate that the inclusion of RECLASS in the model raises the coefficient

\footnotetext{
17 Alternatively, summing the coefficients across the relevant book value and comprehensive income terms involving AUGL in the full market value model Eq. (6) yields a total coefficient on AUGL of $\beta_{2}+\beta_{7}=0.72+0.56=1.28$. This coefficient remains fairly close to the expected coefficient of one for transitory gains and losses and is insignificant. We do not use this alternative approach in the text because, in our observation, researchers generally do not sum coefficients across overlapping book value and comprehensive income terms in Ohlson's market value models this fashion. See footnote 13 for related discussion.
} 
Table 3 Pricing implications of reclassifications

\begin{tabular}{|c|c|c|c|c|c|}
\hline & \multicolumn{5}{|c|}{ Dependent variable: MV } \\
\hline & I & II & III & IV & V \\
\hline \multicolumn{6}{|c|}{ Panel A: Market value model } \\
\hline Intercept & $9.09 * * *$ & $4.55^{*}$ & $4.39 *$ & 2.71 & 2.35 \\
\hline \multicolumn{6}{|l|}{ BV } \\
\hline \multicolumn{6}{|l|}{$\mathrm{BV}^{\mathrm{afs}}$} \\
\hline COST & $1.44 * * *$ & & & $0.38 * * *$ & 0. $40^{* * *}$ \\
\hline AUGL & $3.25 * *$ & & & 1.45 & 0.72 \\
\hline $\mathrm{BV}^{\text {other }}$ & $1.37 * * *$ & & & $0.34 * * *$ & $0.37 * * *$ \\
\hline \multicolumn{6}{|l|}{$\mathrm{CI}$} \\
\hline \multicolumn{6}{|l|}{ NIBEX } \\
\hline RECLASS & & & $9.88^{* * * *}$ & & $7.84 * * *$ \\
\hline NIBEX $^{\text {other }}$ & & $12.22 * * *$ & $13.34 * * *$ & $9.38 * * *$ & $10.84^{* * *}$ \\
\hline EX & & 2.00 & 2.05 & 1.68 & 1.82 \\
\hline \multicolumn{6}{|l|}{ OCI } \\
\hline$\Delta$ AUGL & & 0.16 & 0.42 & 0.30 & 0.56 \\
\hline $\mathrm{OCI}^{\text {other }}$ & & $1.28 * * *$ & $1.49 * * *$ & $1.14 * * *$ & $1.29 * * *$ \\
\hline $\mathrm{N}$ & 1,033 & 1,033 & 1,033 & 1,033 & 1,033 \\
\hline $\mathrm{R}^{2}$ & 0.55 & 0.70 & 0.72 & 0.73 & 0.75 \\
\hline$\beta_{4}-\beta_{7}$ & - & - & $9.46^{* * *}$ & - & $7.28 * * *$ \\
\hline
\end{tabular}

Dependent variable: market-adjusted return

I II III

Panel B: Returns model

$\begin{array}{llll}\text { Intercept } & 0.04 & 0.03 & 0.03 \\ \text { RECLASS } & & & 6.01^{* *} \\ \Delta \text { NIBEX }^{\text {other }} & 2.70^{* * *} & 2.71^{* * *} & 2.86^{* * *} \\ \mathrm{EX} & -0.11 & -0.36 & -0.29 \\ \Delta \text { AUGL } & & 1.59^{*} & 1.74^{* *} \\ \mathrm{OCI}^{\text {other }} & & -0.83 & -0.68 \\ \mathrm{~N} & 884 & 884 & 884 \\ \mathrm{R}^{2} & 0.05 & 0.13 & 0.16 \\ \mathrm{~b}_{1}-\mathrm{b}_{4} & & & 4.27^{* *}\end{array}$

Panel A reports pooled estimations of nested and full versions of the market value model [Eq. (6)], which regresses market value of owners' equity (MV) on the (after-tax) components of book value of owners' equity (BV) and comprehensive income (CI). See Table 1 for description of these variables. The components of BV are COST, AUGL, and $\mathrm{BV}^{\text {other; }}$ they are deflated by the number of shares outstanding at fiscal year-end. The components of CI are RECLASS, NIBEX ${ }^{\text {other }}$, EX, $\triangle \mathrm{AUGL}$, and $\mathrm{OCI}^{\text {other }}$; they are deflated by the number of shares used in calculating earnings per share. Panel B reports pooled estimations of nested and full versions of the returns model [Eq. (7)], which regresses market-adjusted return (raw return minus the value-weighted market return) for the 12-month period ending at the end of the fourth month after a bank's fiscal year-end on RECLASS, $\triangle \mathrm{NIBEX}{ }^{\text {other }}$, EX, $\triangle \mathrm{AUGL}$, and $\mathrm{OCI}^{\text {other}}$; these variables are deflated by beginning-of-returninterval market capitalization. The total coefficient on RECLASS, i.e., the difference of the coefficients on RECLASS and $\triangle$ AUGL, is denoted $\beta_{4}-\beta_{7}\left(b_{1}-b_{4}\right)$ in the market value (returns) model. Year fixed effects are included in all regressions, and $t$-statistics are adjusted for clustering of observations by firm (Petersen 2009). $*, * *$, and *** two-tailed statistical significance at 10,5 , and $1 \%$ levels, respectively 
on NIBEX $^{\text {other }}$ from 9.38 to 10.84 , with both coefficients significant at the $1 \%$ level. However, the difference of these coefficients is again insignificant.

Table 3 Panel B presents the results of estimating the returns model Eq. (7). As benchmarks for the estimation of the full Eq. (7) reported in column III, we briefly discuss the estimation of two nested versions of the equation. The first nested model includes only $\triangle \mathrm{NIBEX}^{\mathrm{other}}$ and $\mathrm{EX}$ and is reported in column I. While the coefficient on $\triangle \mathrm{NIBEX}^{\text {other }}$ is 2.70 and significant at the $1 \%$ level, consistent with $\triangle$ NIBEX $^{\text {other }}$ exhibiting some degree of permanence, this nested model has an $\mathrm{R}^{2}$ of only $5 \%$. The second nested model includes all explanatory variables other than RECLASS and is reported in column II. The coefficients on $\triangle$ NIBEX $^{\text {other }}$ and EX do not change appreciably from column I. The coefficient on $\triangle$ AUGL is positive at 1.59 and significant at the $10 \%$ level; while this coefficient is above one, it is not significantly so, and it is only about half of the coefficient obtained by Chambers et al. (2007) in their returns model. The $\mathrm{R}^{2}$ rises considerably from $5 \%$ in column I to $13 \%$ in column II, indicating considerably improved goodness of fit.

The estimation of full model reported in column III yields an $\mathrm{R}^{2}$ of $16 \%$, indicating further improved goodness of fit. The total coefficient on RECLASS is $\mathrm{b}_{1}-\mathrm{b}_{4}=6.01-1.74=4.27$, significant at the $5 \%$ level. This total coefficient is considerably higher than the coefficient of 2.86 on $\triangle \mathrm{NIBEX}^{\mathrm{other}}$, despite the fact that the inclusion of the additional variables raises the latter coefficient slightly from the results for the nested models reported in column I and II. As discussed in Sect. 3, a higher coefficient on RECLASS than on NIBEX ${ }^{\text {other }}$ is possible if, for example, RECLASS perfectly offsets a fixed proportion less than $100 \%$ of the transitory component of NIBEX ${ }^{\text {other }}$. Opposite to the decreasing effect of the inclusion of the RECLASS on the coefficient on AUGL in the market value model, the coefficient on $\triangle$ AUGL increases slightly to 1.74 and increases in significance to the $5 \%$ level.

Comparison of the full models without and with RECLASS reported in columns II and III indicates that the inclusion of RECLASS in the model raises the coefficient on $\triangle \mathrm{NIBEX}^{\mathrm{other}}$ from 2.71 to 2.86 , with both coefficients significant at the $1 \%$ level. However, the difference of these coefficients is insignificant.

In summary, the results of the market value and returns model analyses indicate investors deem RECLASS to have high incremental pricing implications beyond $(\Delta)$ AUGL and the other explanatory variables in those models, consistent with the alternative hypothesis $\mathrm{H} 1 \mathrm{~A}$.

\section{Determinants of the pricing implications of RECLASS}

In this section, we examine two possible explanations for the pricing implications of RECLASS. First, we consider the possibility that the measurement of unrealized gains and losses is unreliable, as critics of fair value accounting often allege. This possibility is inconsistent with the findings discussed above that AUGL exhibits at least normal pricing implications and also with the high liquidity of most AFS securities. Second, we consider the possibility that RECLASS helps investors predict future bank performance. 


\subsection{Unreliable fair value measurement}

To test whether the pricing implications of RECLASS are attributable to unreliable fair value measurement, each year we estimate the full market value model Eq. (6) and the full returns model Eq. (7) for two equal-sized subsamples formed based on a proxy for the liquidity of AFS securities. Following Barth (1994), we use the percentage of AFS securities that are US Treasuries or other US Government securities (Treasuries) as our proxy. In untabulated robustness tests, we include broader measures of liquid securities (Treasuries plus common stock and Treasuries plus common stock and corporate bonds), with substantively the same results.

The results are reported in Table 4 Panel A for the market value model and Panel B for the returns model. For the market value model, the total coefficient on RECLASS is higher and more significant for the high liquidity subsample. Specifically, the total coefficient on RECLASS is $\beta_{4}-\beta_{7}=11.26-3.83=7.43$ in the high liquidity subsample compared to $2.93+1.14=4.07$ in the low liquidity subsample, with the difference significant at the $5 \%$ level. For the returns model, the total coefficient on RECLASS also is higher and more significant for the high liquidity subsample. Specifically, the total coefficient on RECLASS is $b_{1}-$ $\mathrm{b}_{4}=8.12-2.63=5.49$ in the high liquidity subsample compared to $3.95-$ $1.47=2.48$ in the low liquidity subsample, with the difference significant at the $10 \%$ level.

Inconsistent with the alternative hypothesis $\mathrm{H} 2 \mathrm{~A}$, the results of both the market value and returns model analyses indicate that the pricing implications of RECLASS do not result from the unreliability of unrealized gains and losses recorded in AUGL.

\subsection{Predicting future bank performance}

As described in Sect. 3, we conduct three distinct analyses to test whether RECLASS's pricing implications are attributable to it enabling investors to predict future bank performance. First, we estimate the full market value and returns models for two equalsized subsamples formed each year based on growth in net interest income, because the prediction of future bank performance is more important and difficult for higher growth banks. ${ }^{18}$ In untabulated robustness tests, we partition based on banks' growth in assets and total revenues, which yields the same inferences.

The results of the growth partitioning analysis are presented in Table 5. In the market value model results reported in Panel A, the coefficient on RECLASS is higher and more significant for the high growth subsample. Specifically, the total coefficient on RECLASS is $\beta_{4}-\beta_{7}=11.68-0.25=11.43$ and significant at the

\footnotetext{
18 Our measures of liquidity and growth are essentially uncorrelated, so that the analyses reported in Table 4 and 5 capture different phenomena. In untabulated analyses, we estimated Eqs. (6) and (7) for the four subsamples formed by the intersections of the two liquidity and two growth subsamples. We find that the coefficients on RECLASS are highest and significant in the high liquidity and high growth subsample, about half the size but still significant at the $10 \%$ level or better for both the high liquidity and low growth subsample and the low liquidity and high growth subsample, and approximately zero and insignificant in the low liquidity and low growth subsamples.
} 
Table 4 Effect of AFS security liquidity (reliability of fair values) on the pricing implications of reclassifications

Panel A reports pooled estimations of the market value model [Eq. (6)], and Panel B reports pooled estimations of the returns model [Eq. (7)] for banks with above and below median liquidity AFS securities (more and less reliable fair values, respectively). See Tables 1 and 3 for description of the models and variables. Liquidity is measured as the percentage of available-for-sale securities invested in US Treasuries and other US government securities. The total coefficient on RECLASS, i.e., the difference of the coefficients on RECLASS and $\triangle \mathrm{AUGL}$, is denoted $\beta_{4}-$ $\beta_{7}\left(b_{1}-b_{4}\right)$ in the market value (returns) model. Year fixed effects are included in all regressions, and $t$-statistics are adjusted for clustering of observations by firm (Petersen 2009). *, **, and *** two-tailed statistical significance at 10,5, and $1 \%$ levels

\section{Panel A: Market value model}

Intercept

BV

$\mathrm{BV}^{\mathrm{afs}}$

COST
AUGL
BV $^{\text {other }}$

CI

NIBEX

RECLASS
NIBEX $^{\text {other }}$
EX
OCI

\section{$\triangle \mathrm{AUGL}$}

$\mathrm{OCI}^{\text {other }}$

$\mathrm{N}$

$\mathrm{R}^{2}$

$\beta_{4}-\beta_{7}$

$\left(\beta_{4}-\beta_{7}\right)^{\mathrm{High}}-\left(\beta_{4}-\beta_{7}\right)^{\text {Low }}$

Panel B: Returns model

\section{Intercept}

RECLASS

$\triangle$ NIBEX $^{\text {other }}$

EX

$\triangle \mathrm{AUGL}$

$\mathrm{OCI}^{\text {other }}$

$\mathrm{N}$

$\mathrm{R}^{2}$

$b_{1}-b_{4}$

$\left(b_{1}-b_{4}\right)^{\text {High }}-\left(b_{1}-b_{4}\right)^{\text {Low }}$
$3.66 * * *$

$4.09 *$

High liquidity

Low liquidity

$\begin{array}{ll}0.61 * * * & 0.69 * * * \\ 1.66 & 2.20 * \\ 0.59 * * * & 0.67 * * *\end{array}$

$11.26 * * *$

$2.93^{*}$

$8.11 * * *$

$7.84 * * *$

$-3.64$

3.40

$3.83^{* *}$
0.83
489

0.83

$7.43 * * *$

$-1.14$

$1.73 * *$

482

0.75

4.07

3.36**

0.04

0.04

8.12**

3.95*

$2.58 * * *$

$2.50 * * *$

$-2.01$

$-2.17$

$2.63 * *$

$1.47 *$

$-0.63$

$-0.84$

419

416

0.18

0.15

$5.49 * *$

2.48

$1 \%$ level in the high growth subsample and only $2.65+0.54=3.19$ and insignificant in the low growth subsample, with the difference of 8.24 significant at the $1 \%$ level. In the returns model analysis reported in Panel B, the total coefficient on RECLASS is $b_{1}-b_{4}=9.07-1.83=7.24$ and significant at the $5 \%$ level in the high growth subsample and only $3.65-1.59=2.06$ and insignificant in the low growth subsample, with the difference of 5.18 significant at the $10 \%$ level. Consistent with the alternative hypothesis $\mathrm{H} 3 \mathrm{~A}$, the results of both the market value and returns models analyses indicate that the pricing implications of RECLASS are stronger for higher growth banks.

Surprisingly, however, the coefficients on NIBEX ${ }^{\text {other }}$ in both the market value and returns models do not vary much or significantly across the growth subsamples. This appears to result in part from our predetermined choice to partition based on 
Table 5 Effect of bank growth on the pricing implications of reclassifications

\begin{tabular}{|c|c|c|}
\hline & $\begin{array}{l}\text { High net int. inc. } \\
\text { growth }\end{array}$ & $\begin{array}{l}\text { Low net int. inc. } \\
\text { growth }\end{array}$ \\
\hline \multicolumn{3}{|c|}{ Panel A: Market value model } \\
\hline Intercept & 3.99 & 1.35 \\
\hline \multicolumn{3}{|l|}{ BV } \\
\hline \multicolumn{3}{|l|}{$\mathrm{BV}^{\mathrm{afs}}$} \\
\hline COST & $0.35 * * *$ & $0.40 * * *$ \\
\hline AUGL & 1.11 & 0.64 \\
\hline $\mathrm{BV}^{\text {other }}$ & $0.28 *$ & $0.40^{* * *}$ \\
\hline \multicolumn{3}{|l|}{ CI } \\
\hline \multicolumn{3}{|l|}{ NIBEX } \\
\hline RECLASS & $11.68 * * *$ & $2.65^{*}$ \\
\hline $\mathrm{NIBEX}^{\text {other }}$ & $11.42 * * *$ & $10.37 * * *$ \\
\hline EX & -4.11 & $8.17 *$ \\
\hline \multicolumn{3}{|l|}{ OCI } \\
\hline$\triangle \mathrm{AUGL}$ & 0.25 & -0.54 \\
\hline $\mathrm{OCI}^{\text {other }}$ & $1.62 * *$ & 0.47 \\
\hline $\mathrm{N}$ & 519 & 513 \\
\hline $\mathrm{R}^{2}$ & 0.71 & 0.80 \\
\hline$\beta_{4}-\beta_{7}$ & $11.43 * * *$ & 3.19 \\
\hline $\begin{array}{l}\left(\beta_{4}-\beta_{7}\right)^{\text {High }}- \\
\quad\left(\beta_{4}-\beta_{7}\right)^{\text {Low }}\end{array}$ & $8.24 * * *$ & \\
\hline \multicolumn{3}{|c|}{ Panel B: Returns model } \\
\hline Intercept & 0.05 & 0.02 \\
\hline RECLASS & $9.07 * *$ & $3.65 *$ \\
\hline$\Delta \mathrm{NIBEX}^{\text {other }}$ & $3.13 * * *$ & $3.31 * * *$ \\
\hline $\mathrm{EX}$ & $-2.92 * *$ & $2.55^{*}$ \\
\hline$\triangle \mathrm{AUGL}$ & 1.83 & 1.59 \\
\hline $\mathrm{OCI}^{\text {other }}$ & -0.53 & -1.12 \\
\hline $\mathrm{N}$ & 447 & 437 \\
\hline $\mathrm{R}^{2}$ & 0.16 & 0.20 \\
\hline $\mathrm{b}_{1}-\mathrm{b}_{4}$ & $7.24 * *$ & 2.06 \\
\hline $\begin{array}{c}\left(b_{1}-b_{4}\right)^{\text {High }}- \\
\quad\left(b_{1}-b_{4}\right)^{\text {Low }}\end{array}$ & $5.18^{*}$ & \\
\hline
\end{tabular}

High net int. inc.

c.
Panel A reports pooled estimations of the market value model [Eq. (6)], and Panel B reports pooled estimations of the returns model [Eq. (7)] for banks with above and below median growth in net interest income. See Tables 1 and 3 for description of the model and variables. The total coefficient on RECLASS, i.e., the difference of the coefficients on RECLASS and $\triangle \mathrm{AUGL}$, is denoted $\beta_{4}-\beta_{7}\left(b_{1}-b_{4}\right)$ in the market value (returns) model. Year fixed effects are included in all regressions, and $t$-statistics are adjusted for clustering of observations by firm (Petersen 2009). *, **, and *** two-tailed statistical significance at 10,5 , and $1 \%$ levels

growth in net interest income, a component of NIBEX ${ }^{\text {other }}$. For example, if we partition on growth in total assets, the coefficients on NIBEX ${ }^{\text {other }}$ increase significantly from the low to high growth subsamples.

Second, we estimate the association of RECLASS with year-ahead CI using Eq. (8). ${ }^{19}$ We also conduct similar analyses replacing year-ahead CI as the dependent variable with two of its components: year-ahead NIBEX ${ }^{\text {other }}$ and RECLASS. We

19 Because RECLASS may be associated with many future years' CI, to maximize the power of the test, the dependent variable ideally would be future CI summed over more than one year in these analyses. We do not do this to avoid losing observations due to the limited number of years of data available. 
Table 6 Association between year-ahead comprehensive income and reclassifications

\begin{tabular}{|c|c|c|c|}
\hline & \multicolumn{3}{|c|}{ Dependent variable } \\
\hline & $\mathrm{CI}_{\mathrm{t}+1}$ & $\operatorname{NIBEX}_{t+1}$ & RECLASS $_{\mathrm{t}+1}$ \\
\hline \multicolumn{4}{|c|}{ Panel A: Overall sample } \\
\hline Intercept & -0.15 & $-0.35^{*}$ & 0.00 \\
\hline \multicolumn{4}{|l|}{ BV } \\
\hline \multicolumn{4}{|l|}{$\mathrm{BV}^{\mathrm{afs}}$} \\
\hline COST & 0.01 & $0.03 * * *$ & -0.00 \\
\hline AUGL & $-0.23^{*}$ & 0.03 & $0.06 * * *$ \\
\hline $\mathrm{BV}^{\text {other }}$ & 0.01 & $0.03 * * *$ & -0.00 \\
\hline \multicolumn{4}{|l|}{ CI } \\
\hline \multicolumn{4}{|l|}{ NIBEX } \\
\hline RECLASS & $0.61 *$ & $0.29 *$ & $0.39 * * *$ \\
\hline NIBEX ${ }^{\text {other }}$ & $0.90 * * *$ & $0.78 * * *$ & 0.01 \\
\hline $\mathrm{EX}$ & -0.08 & -0.35 & $0.11 * *$ \\
\hline \multicolumn{4}{|l|}{ OCI } \\
\hline$\Delta \mathrm{AUGL}$ & -0.23 & -0.12 & $0.05 * *$ \\
\hline $\mathrm{OCI}^{\text {other }}$ & $0.24 * *$ & 0.03 & $-0.01 *$ \\
\hline $\mathrm{N}$ & 973 & 973 & 959 \\
\hline $\mathrm{R}^{2}$ & 0.54 & 0.69 & 0.19 \\
\hline$\gamma_{4}-\gamma_{7}$ & $0.84 * *$ & $0.41 *$ & $0.34 * * *$ \\
\hline \multicolumn{4}{|c|}{ Panel B: High net interest income growth sub-sample } \\
\hline Intercept & -0.25 & -0.18 & 0.04 \\
\hline \multicolumn{4}{|l|}{ BV } \\
\hline \multicolumn{4}{|l|}{$\mathrm{BV}^{\mathrm{afs}}$} \\
\hline COST & 0.01 & $0.02 * *$ & -0.00 \\
\hline AUGL & $-0.39 *$ & 0.00 & $0.06 * *$ \\
\hline $\mathrm{BV}^{\text {other }}$ & 0.01 & $0.02 * *$ & $-0.01 *$ \\
\hline \multicolumn{4}{|l|}{$\mathrm{CI}$} \\
\hline \multicolumn{4}{|l|}{ NIBEX } \\
\hline RECLASS & $1.20 *$ & $0.75 * *$ & $0.58 * * *$ \\
\hline NIBEX ${ }^{\text {other }}$ & $1.02 * * *$ & $0.84 * * *$ & 0.01 \\
\hline EX & -0.65 & $-1.03 *$ & $0.05^{*}$ \\
\hline \multicolumn{4}{|l|}{ OCI } \\
\hline$\triangle \mathrm{AUGL}$ & 0.15 & -0.16 & $0.07 * *$ \\
\hline $\mathrm{OCI}^{\text {other }}$ & $0.31 * *$ & $0.10 * *$ & -0.01 \\
\hline $\mathrm{N}$ & 490 & 490 & 485 \\
\hline $\mathrm{R}^{2}$ & 0.58 & 0.69 & 0.27 \\
\hline$\gamma_{4}-\gamma_{7}$ & $1.05^{*}$ & $0.91 * * *$ & $0.51 * * *$ \\
\hline \multicolumn{4}{|c|}{ Panel C: Low net interest income growth sub-sample } \\
\hline Intercept & -0.03 & $-0.39 * * *$ & -0.01 \\
\hline \multicolumn{4}{|l|}{$\mathrm{BV}$} \\
\hline $\mathrm{BV}^{\mathrm{afs}}$ & & & \\
\hline
\end{tabular}


Table 6 continued

\begin{tabular}{|c|c|c|c|}
\hline & \multicolumn{3}{|c|}{ Dependent variable } \\
\hline & $\mathrm{CI}_{\mathrm{t}+1}$ & NIBEX $_{t+1}$ & $\operatorname{RECLASS}_{\mathrm{t}+1}$ \\
\hline COST & 0.02 & $0.03 * * *$ & -0.00 \\
\hline AUGL & -0.17 & 0.04 & $0.05 * *$ \\
\hline $\mathrm{BV}^{\text {other }}$ & 0.02 & $0.03^{* * *}$ & 0.00 \\
\hline \multicolumn{4}{|l|}{ CI } \\
\hline \multicolumn{4}{|l|}{ NIBEX } \\
\hline RECLASS & -0.09 & -0.09 & $0.24 * * *$ \\
\hline NIBEX $^{\text {other }}$ & $0.76 * * *$ & $0.77 * * *$ & 0.01 \\
\hline EX & 0.41 & 0.38 & $0.26^{*}$ \\
\hline \multicolumn{4}{|l|}{ OCI } \\
\hline$\triangle \mathrm{AUGL}$ & $-0.67^{*}$ & -0.15 & 0.02 \\
\hline $\mathrm{OCI}^{\text {other }}$ & 0.12 & $-0.08 * *$ & -0.01 \\
\hline $\mathrm{N}$ & 482 & 482 & 473 \\
\hline $\mathrm{R}^{2}$ & 0.55 & 0.71 & 0.16 \\
\hline$\gamma_{4}-\gamma_{7}$ & 0.58 & 0.06 & $0.22 * * *$ \\
\hline
\end{tabular}

This table reports pooled estimations of regressions of year-ahead comprehensive income (CI) and two its components-year-ahead net income before extraordinary items and discontinued operations (NIBEX) and reclassification of gains and losses on AFS securities upon realization (RECLASS) — on the same explanatory variables as the market value model [Eq. (6)]. See Tables 1 and 3 for description of that model and the explanatory variables. The total coefficient on RECLASS, i.e., the difference of the coefficients on RECLASS and $\triangle$ AUGL, is denoted $\gamma_{4}-\gamma_{7}$. Panel A reports results for the overall sample, and Panel $\mathrm{B}(\mathrm{C})$ reports results for the high (low) growth in net interest income subsamples. Year fixed effects are included in all regressions, and $t$-statistics are adjusted for clustering of observations for the same firm (Petersen 2009). *, **, and *** two-tailed statistical significance at 10, 5, and $1 \%$ levels, respectively

examine these components of $\mathrm{CI}$ because the descriptive analyses reported in Table 2 suggest that banks smooth net income using RECLASS, and so it should predict yearahead NIBEX ${ }^{\text {other }}$, and that RECLASS reflects gradual realization of gains and losses, and so current RECLASS should predict year-ahead RECLASS. We conduct these analyses for the overall sample as well as for the growth subsamples examined in Table 5. We do not tabulate the results for the liquidity subsamples because we neither expect nor find that these subsamples have distinct implications for predicting future bank performance. Parallel to the analyses of market value pricing implications discussed in Sect. 5, we examine the total coefficient $\gamma_{4}-\gamma_{7}$ on RECLASS in Eq. (8). Because RECLASS has higher pricing implications for the high growth subsample, it should also have higher total coefficients $\gamma_{4}-\gamma_{7}$ in Eq. (8) for that subsample.

We report the results of these analyses in Table 6. Panels A, B, and C report the results for the overall sample and the high and low growth subsamples, respectively. In the overall sample analysis reported in Panel $\mathrm{A}$, the total coefficient on RECLASS is significantly positive at the $5 \%$ level in the CI regression, the $10 \%$ level in the NIBEX regression, and at the $1 \%$ level in the RECLASS regression. Hence RECLASS helps investors predict future bank performance, consistent with the alternative hypothesis H4A. 
Table 7 Year-ahead comprehensive income and pricing implications of reclassifications

\begin{tabular}{|c|c|c|}
\hline & \multicolumn{2}{|c|}{ High net int. inc. growth } \\
\hline & Without $\mathrm{CI}_{\mathrm{t}+1}$ & With $\mathrm{CI}_{\mathrm{t}+1}$ \\
\hline \multicolumn{3}{|l|}{ Panel A: Market value model } \\
\hline Intercept & 3.14 & 4.51 \\
\hline \multicolumn{3}{|l|}{$\mathrm{BV}_{\mathrm{t}}$} \\
\hline \multicolumn{3}{|l|}{$\mathrm{BV}_{\mathrm{t}}^{\mathrm{afs}}$} \\
\hline $\operatorname{COST}_{\mathrm{t}}$ & $0.32 * * *$ & $0.20 *$ \\
\hline $\mathrm{AUGL}_{\mathrm{t}}$ & 0.52 & 1.38 \\
\hline $\mathrm{BV}_{\mathrm{t}}^{\mathrm{other}}$ & $0.25 *$ & 0.13 \\
\hline \multicolumn{3}{|l|}{$\mathrm{CI}_{\mathrm{t}}$} \\
\hline \multicolumn{3}{|l|}{ NIBEX $_{t}$} \\
\hline RECLASS $_{\mathrm{t}}$ & $12.89 * * *$ & $9.77 *$ \\
\hline $\mathrm{NIBEX}_{\mathrm{t}}^{\mathrm{other}}$ & $11.70 * * *$ & $5.89 * * *$ \\
\hline $\mathrm{EX}_{\mathrm{t}}$ & -3.85 & 2.34 \\
\hline \multicolumn{3}{|l|}{$\mathrm{OCI}_{\mathrm{t}}$} \\
\hline$\Delta \mathrm{AUGL}_{\mathrm{t}}$ & 0.43 & 1.50 \\
\hline $\mathrm{OCI}_{\mathrm{t}}^{\text {other }}$ & $1.86^{* *}$ & $0.94 * *$ \\
\hline \multicolumn{3}{|l|}{$\mathrm{CI}_{\mathrm{t}+1}$} \\
\hline \multicolumn{3}{|l|}{$\operatorname{NIBEX}_{t+1}$} \\
\hline RECLASS $_{\mathrm{t}+1}$ & & $4.73 *$ \\
\hline NIBEX $X_{t+1}^{\text {other }}$ & & $6.98 * * *$ \\
\hline $\mathrm{EX}_{\mathrm{t}+1}$ & & 0.19 \\
\hline \multicolumn{3}{|l|}{$\mathrm{OCI}_{\mathrm{t}+1}$} \\
\hline$\Delta \mathrm{AUGL}_{\mathrm{t}+1}$ & & 1.50 \\
\hline $\mathrm{OCI}_{\mathrm{t}+1}^{\text {other }}$ & & 0.78 \\
\hline $\mathrm{N}$ & 485 & 485 \\
\hline $\mathrm{R}^{2}$ & 0.71 & 0.77 \\
\hline$\beta_{4}-\beta_{7}$ & $12.46^{* * * *}$ & $8.27 * *$ \\
\hline$\left(\beta_{4}-\beta_{7}\right)^{\text {Without }}-\left(\beta_{4}-\beta_{7}\right)^{\text {With }}$ & $4.19 * *$ & \\
\hline \multicolumn{3}{|l|}{ Panel B: Returns model } \\
\hline Intercept & 0.05 & -0.00 \\
\hline RECLASS $_{\mathrm{t}}$ & $10.12 * * *$ & $6.79 * *$ \\
\hline$\Delta \mathrm{NIBEX}_{\mathrm{t}}^{\mathrm{other}}$ & $2.41 * *$ & $3.31 * * *$ \\
\hline $\mathrm{EX}_{\mathrm{t}}$ & -2.95 & -2.89 \\
\hline$\Delta \mathrm{AUGL}_{\mathrm{t}}$ & $1.75^{* *}$ & 1.08 \\
\hline $\mathrm{OCI}_{\mathrm{t}}^{\text {other }}$ & -0.40 & -0.57 \\
\hline RECLASS $_{\mathrm{t}+1}$ & & $6.22 * * *$ \\
\hline$\Delta \mathrm{NIBEX}_{\mathrm{t}+1}^{\mathrm{other}}$ & & $3.43 * * *$ \\
\hline $\mathrm{EX}_{\mathrm{t}+1}$ & & 2.22 \\
\hline$\Delta \mathrm{AUGL}_{\mathrm{t}+1}$ & & 1.07 \\
\hline $\mathrm{OCI}_{\mathrm{t}+1}^{\text {other }}$ & & -0.76 \\
\hline $\mathrm{N}$ & 414 & 414 \\
\hline
\end{tabular}


Table 7 continued

\begin{tabular}{lll}
\hline & \multicolumn{2}{l}{ High net int. inc. growth } \\
\cline { 2 - 3 } & Without $\mathrm{CI}_{\mathrm{t}+1}$ & ${\text { With } \mathrm{CI}_{\mathrm{t}+1}}$ \\
\hline $\mathrm{R}^{2}$ & 0.16 & 0.40 \\
$\mathrm{~b}_{1}-\mathrm{b}_{4}$ & $8.37^{* *}$ & $5.71^{*}$ \\
$\left(\mathrm{~b}_{1}-\mathrm{b}_{4}\right)^{\text {Without }}-\left(\mathrm{b}_{1}-\mathrm{b}_{4}\right)^{\text {With }}$ & $2.66^{* *}$ & \\
\hline
\end{tabular}

This table reports pooled estimations of the market value model [Eqs. (6)] and the returns model [Eq. (7)] for banks with above and below median growth in net interest income, both with and without the components of year-ahead comprehensive income included. See Tables 1 and 3 for description of the market value and returns models and variables. $\beta_{4}-\beta_{7}\left(b_{1}-b_{4}\right)$ denotes the total coefficient on RECLASS, i.e., the difference of the coefficients on RECLASS and $\triangle \mathrm{AUGL}$, in the market value (returns) model. Year fixed effects are included in all regressions, and $t$-statistics are adjusted for clustering of observations by firm (Petersen 2009). *, **, and *** two-tailed statistical significance at 10,5 , and $1 \%$ levels

In the growth subsample results reported in Panels B and C, the total coefficient on RECLASS is consistently higher and more significant for the high growth subsample. In the $\mathrm{CI}_{\mathrm{t}+1}$ regression, the total coefficient is about three times more positive and significant at the $10 \%$ level in the high growth subsample and insignificant in the low growth subsample. In the NIBEX $_{t+1}$ regression, the total coefficient is about thirty times more positive and significant at the $1 \%$ level in the high growth subsample and insignificant in the low growth subsample. In the RECLASS $_{\mathrm{t}+1}$ regression, the total coefficient is about three times more positive in the high growth subsample but significant at the same $1 \%$ level in the two subsamples. These results are all consistent with the alternative hypothesis H4A.

Third, we control for the components of $\mathrm{CI}_{\mathrm{t}+1}$ in the market value and returns models. We tabulate results for the high growth subsample only, because the total coefficients on RECLASS are insignificant in the low growth subsample whether or not we control for the components of $\mathrm{CI}_{\mathrm{t}+1}$. The results are reported in Table 7 Panel A for the market value model and Panel B for the returns model. The total coefficient on RECLASS declines by about a third and significantly at the $5 \%$ level in both the market value and returns models consistent with RECLASS's high pricing implications being attributable in significant part to it helping investors predict future bank performance. These results are consistent with the alternative hypothesis H5A.

In summary, RECLASS predicts banks' year-ahead CI, more so for banks with more liquid AFS securities and higher growth. This predictive power explains a significant part of the pricing implications of RECLASS reported in Tables 3 and 5.

\subsection{Other determinants considered}

In untabulated analyses, we considered four other possible determinants of the implications of RECLASS for pricing or future bank performance. First, as discussed above, in our sample RECLASS almost always reflects economic realization of gains and losses. Such realization may occur because the bank needs cash. Second, banks' Tier 1 regulatory capital is increased by their realization of gains (Moyer 1990). During our sample period, however, almost all US banks had 
ample access to liquidity and were well capitalized, and so these possible determinants are a priori unlikely to explain the pricing implications of RECLASS. Consistent with this, we found no evidence that RECLASS is associated with cash on hand (defined as cash and cash equivalents divided by total assets) or regulatory capital (defined as Tier 1 risk-based capital ratio), or that partitioning Eqs. (6)-(8) on above versus below median values of these variables affects the implications of RECLASS for pricing or future bank performance.

Third, banks may realize gains and losses for tax purposes. We found no evidence that RECLASS is associated with tax status (defined as amount of taxexempt interest income as a percentage of total interest income to proxy for marginal tax rate, as in Collins et al. 1995), or that partitioning Eqs. (6)-(8) on above versus below median values of this variable affects the implications of RECLASS for pricing or future bank performance.

Fourth, given uncertainty about the reliability of banks' reported unrealized gains and losses, we consider the possibility that investors react more to banks' realized gains and losses when they have the opposite sign of (i.e., contradict rather than conform to) unrealized gains and losses. We partition the observations into four groups based on RECLASS above versus below zero and beginning AUGL ${ }^{20}$ above versus below the mean for the sample that year. We pool the two groups where RECLASS and AUGL conflict (i.e., RECLASS $<0$ and AUGL above median and RECLASS $>0$ and AUGL below median) and the two groups where the variables conform. We find no evidence that the coefficient on RECLASS is higher when RECLASS and AUGL contradict rather than conform.

\section{Conclusion}

In this study, we find that realized gains and losses for a sample of large commercial banks' AFS securities have pricing implications incremental to accumulated unrealized gains and losses and extensive decompositions of book value and comprehensive income. Moreover, we find that the coefficient on realized gains and losses is closer to the coefficient on the relatively permanent net income before extraordinary items than to the coefficients on the relatively transitory accumulated unrealized gains and losses and other components of comprehensive income. We also provide evidence that the pricing implications of realized gains and losses are attributable to realized gains and losses helping investors predict future bank performance, more so for higher growth banks, rather than to realized gains and losses remedying the unreliability of fair value accounting for AFS securities. The lack of evidence that the reliability of fair values affects the pricing implications of realized gains and losses may reflect our largely favorable 1998-2006 sample period.

Importantly, our sample period is after the effective date of SFAS No. 130. This standard required firms to prominently present realized gains and losses and other

\footnotetext{
${ }^{20}$ We partition by beginning, not ending, AUGL so that the partitioning variables are not tautologically related.
} 
components of comprehensive income in their financial statements. Our results regarding the pricing implications of realized gains and losses are much stronger than the corresponding prior results in Barth (1994) and, to a lesser extent, Ahmed and Takeda (1995). Both of these studies examine sample periods ending prior to the effective date of SFAS No. 130 in 1998 or any other fair value accounting or disclosure standard issued by the FASB.

The difference between our findings and those of Barth (1994) and Ahmed and Takeda (1995) mirror the difference between the findings of studies examining the pricing implications of other comprehensive pre-SFAS No. 130 (Dhaliwal et al. 1999; O'Hanlon and Pope 1999) versus post-SFAS No. 130 (Biddle and Choi 2006; Chambers et al. 2007). Collectively, these studies strongly suggest that prominent presentation in financial statements increases the pricing implications of the components of comprehensive income. Our results may also reflect investors' increasing familiarity with fair value accounting numbers over time.

Subject to caveats detailed in the introduction about the conclusions that can be drawn from our market association study and the magnitude and pricing implications of income smoothing using realization of gains and losses, our findings suggest that the FASB should continue to require information about realized gains and losses, an amortized cost accounting construct, to be prominently presented in financial statements within the fair-value-accounting framework for AFS securities. The FASB currently intends to require parenthetical presentation on the balance sheet of the amortized costs for many financial instruments recognized at fair value. While this proposal likely has political motivations, we find it a sensible way to preserve amortized cost accounting while still broadening fair value accounting for financial instruments.

Acknowledgments Comments and suggestions from Anne Christine d'Arcy, Jonathan Glover, Pierre Liang, Jack Stecher, Danqing Yang and seminar participants at Carnegie Mellon University, Chinese University of Hong Kong, Nanjing University, University of Lausanne, Columbia Business School's 2010 Burton Workshop, the University of Texas at Austin's 2011 Spring Research Conference, and two anonymous referees are gratefully acknowledged. We thank Jialu Shan and Joseph Cadora for research and editorial assistance.

\section{Appendix}

SFAS 130 requires US firms to disclose comprehensive income and its components, including the reclassification of accumulated other comprehensive income associated with realization of gains and losses for AFS securities, in their financial reports. This appendix provides representative examples of banks' disclosures.

Other comprehensive income disclosures

Banks typically disclose the components of comprehensive income either in the statement of owners' equity or in a separate table. We provide an example of each of these formats below, enclosing the reclassifications in boxes for easy identification.

Statement of Owners' Equity Example: 


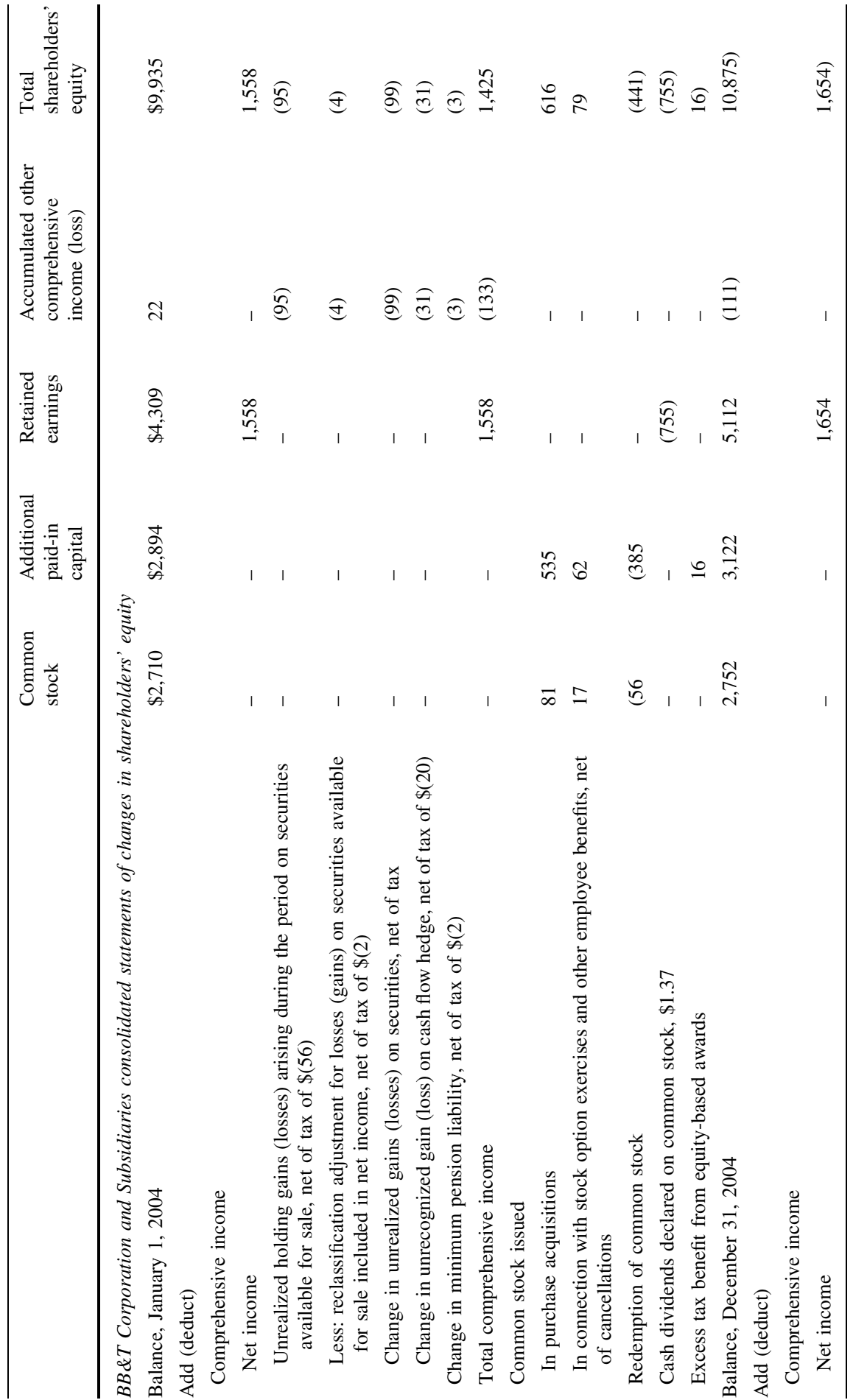




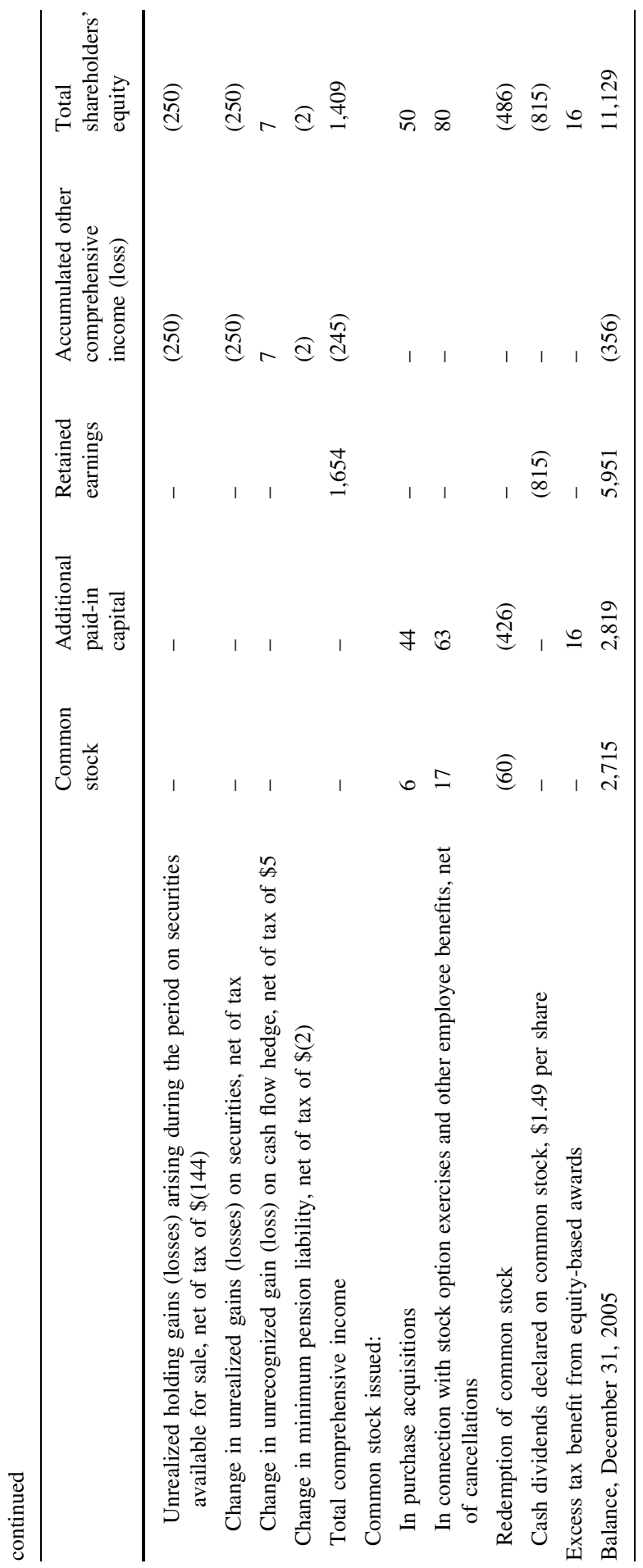


Separate Table Example:

\begin{tabular}{|c|c|c|c|}
\hline For the years ended December 31 (in thousands) & 2003 & 2002 & 2001 \\
\hline \multicolumn{4}{|l|}{$\begin{array}{l}\text { North Fork Bancorporation consolidated statements } \\
\text { of comprehensive income }\end{array}$} \\
\hline Net income & $\$ 396,365$ & $\$ 416,893$ & $\$ 331,484$ \\
\hline \multicolumn{4}{|l|}{ Other comprehensive income } \\
\hline \multicolumn{4}{|l|}{ Unrealized (losses)/gains on securities } \\
\hline Changes in unrealized gains arising during the year & $(44,434)$ & 32,166 & 34,197 \\
\hline Less: reclassification adjustment for gains included in net income & $(15,762)$ & $(4,517)$ & $(8,729)$ \\
\hline Changes in unrealized gains arising during the year & $(60,196)$ & 27,649 & 25,468 \\
\hline Related tax effect on unrealized gains arising during the year & 25,884 & $(11,889)$ & $(10,951)$ \\
\hline Net change in unrealized gains arising during the year & $(34,312)$ & 15,760 & 14,517 \\
\hline \multicolumn{4}{|l|}{ Unrealized gains/(losses) on derivative instruments } \\
\hline Changes in unrealized (losses)/gains arising during the year & $(5,465)$ & $(46,992)$ & $(33,833)$ \\
\hline $\begin{array}{l}\text { Add: reclassification adjustment for expenses/losses included } \\
\text { in net income }\end{array}$ & 30,512 & 32,763 & 9,500 \\
\hline Changes in unrealized (losses)/gains arising during the year & 25,047 & & \\
\hline $\begin{array}{l}\text { Related tax effect on changes in unrealized gains arising } \\
\text { during the year }\end{array}$ & $(10,770)$ & 6,119 & 10,463 \\
\hline Net change in unrealized gains arising during the year & 14,277 & $(8,110)$ & $(13,870)$ \\
\hline Net other comprehensive (loss)/income & $\$(20,035)$ & $\$ 7,650$ & $\$ 647$ \\
\hline Comprehensive income & $\$ 376,330$ & $\$ 424,543$ & $\$ 332,131$ \\
\hline
\end{tabular}

\section{Reclassification disclosures}

In addition to the disclosures above, banks typically disclose reclassifications in a separate table, as shown in the following example.

The following table presents the after-tax changes in net unrealized holdings gains (losses), reclassification adjustments for realized gains and losses on AFS securities and cash flow hedges, changes resulting from foreign currency translation adjustments (including the impact of related derivatives), net gains and losses and prior service costs from pension and OPEB plans, and amortization of pension an OPEB amounts into Net Income. The tale also reflects the adjustment to Accumulated other comprehensive income (loss) resulting from initial application of SFAS 158 to the Firm's defined benefit pension and OPEB plans. Reclassification adjustments include amounts recognized in Net income that had been recorded previously in Other comprehensive income (loss). 


\begin{tabular}{|c|c|c|c|c|c|c|c|c|c|}
\hline \multirow{2}{*}{$\begin{array}{l}\text { Year ended } \\
\text { December } 31 \text {, } \\
\text { (in millions) }\end{array}$} & \multicolumn{3}{|l|}{2007} & \multicolumn{3}{|l|}{2008} & \multicolumn{3}{|l|}{2009} \\
\hline & $\begin{array}{l}\text { Before } \\
\operatorname{tax}\end{array}$ & $\begin{array}{l}\text { Tax } \\
\text { effect }\end{array}$ & $\begin{array}{l}\text { After } \\
\text { tax }\end{array}$ & $\begin{array}{l}\text { Before } \\
\operatorname{tax}\end{array}$ & $\begin{array}{l}\text { Tax } \\
\text { effect }\end{array}$ & $\begin{array}{l}\text { After } \\
\text { tax }\end{array}$ & $\begin{array}{l}\text { Before } \\
\operatorname{tax}\end{array}$ & $\begin{array}{l}\text { Tax } \\
\text { effect }\end{array}$ & $\begin{array}{l}\text { After } \\
\operatorname{tax}\end{array}$ \\
\hline \multicolumn{10}{|c|}{ Unrealized gains (losses) on AFS securities } \\
\hline $\begin{array}{l}\text { Net unrealized } \\
\text { holdings gains } \\
\text { (losses) arising } \\
\text { during the } \\
\text { period }\end{array}$ & $\$ 431$ & $\$(176)$ & $\$ 255$ & $\$(403)$ & $\$ 144$ & $\$(259)$ & $\$(1,706)$ & $\$ 648$ & $\$(1,058)$ \\
\hline $\begin{array}{l}\text { Reclassification } \\
\text { adjustment for } \\
\text { realized } \\
\text { (gains) losses } \\
\text { included in } \\
\text { Net Income }\end{array}$ & 164 & (67) & 97 & 797 & (285) & 512 & 1,443 & (548) & 895 \\
\hline Net change & 595 & (243) & 352 & 394 & (141) & 253 & (263) & 100 & (163) \\
\hline
\end{tabular}

Source: JPMorgan Chase \& Co., 2007 Annual Report, p. 163

Some banks also provide this reclassification information along with a roll forward of the balances of accumulated other comprehensive income in a table.

\section{Note 17. Accumulated other comprehensive income}

The Bancorp has elected to present the disclosures required by SFAS No. 130, "Reporting of Comprehensive Income," in the Consolidated Statements of changes in Shareholders' Equity and in the following table. Disclosure of the reclassification adjustments, related tax effects allocated to other comprehensive income and accumulated other comprehensive income as of and for the years ended December 31 were as follows:

\begin{tabular}{|c|c|c|c|c|c|c|}
\hline \multirow[t]{2}{*}{ ( $\$$ in millions) } & \multicolumn{3}{|c|}{$\begin{array}{l}\text { Total other } \\
\text { comprehensive income }\end{array}$} & \multicolumn{3}{|c|}{$\begin{array}{l}\text { Total accumulated other } \\
\text { comprehensive income }\end{array}$} \\
\hline & $\begin{array}{l}\text { Pretax } \\
\text { activity }\end{array}$ & $\begin{array}{l}\text { Tax } \\
\text { effect }\end{array}$ & $\begin{array}{l}\text { Net } \\
\text { activity }\end{array}$ & $\begin{array}{l}\text { Beginning } \\
\text { balance }\end{array}$ & $\begin{array}{l}\text { Net } \\
\text { activity }\end{array}$ & $\begin{array}{l}\text { Ending } \\
\text { balance }\end{array}$ \\
\hline \multicolumn{7}{|l|}{2007} \\
\hline Gains on available-for-sale securities & $\$ 60$ & $(23)$ & 37 & & & \\
\hline $\begin{array}{l}\text { Reclassification adjustment for net gains } \\
\text { recognized in net income }\end{array}$ & $(21)$ & 9 & (12) & & & \\
\hline $\begin{array}{l}\text { Unrecognized gains (losses) on available- } \\
\text { for-sale securities }\end{array}$ & 39 & (14) & 25 & $(119)$ & 25 & (94) \\
\hline Gains on cash flow hedge derivatives & 42 & $(15)$ & 27 & & & \\
\hline $\begin{array}{l}\text { Reclassification adjustment for net gains } \\
\text { on cash flow hedge derivatives } \\
\text { recognized in net income }\end{array}$ & (1) & - & (1) & & & \\
\hline
\end{tabular}




\begin{tabular}{|c|c|c|c|c|c|c|}
\hline \multirow[t]{2}{*}{ (\$ in millions) } & \multicolumn{3}{|c|}{$\begin{array}{l}\text { Total other comprehensive } \\
\text { income }\end{array}$} & \multicolumn{3}{|c|}{$\begin{array}{l}\text { Total accumulated other } \\
\text { comprehensive income }\end{array}$} \\
\hline & $\begin{array}{l}\text { Pretax } \\
\text { activity }\end{array}$ & $\begin{array}{l}\text { Tax } \\
\text { effect }\end{array}$ & $\begin{array}{l}\text { Net } \\
\text { activity }\end{array}$ & $\begin{array}{l}\text { Beginning } \\
\text { balance }\end{array}$ & $\begin{array}{l}\text { Net } \\
\text { activity }\end{array}$ & $\begin{array}{l}\text { Ending } \\
\text { balance }\end{array}$ \\
\hline $\begin{array}{l}\text { Unrecognized gains (losses) on cash } \\
\text { flow hedge derivatives }\end{array}$ & 41 & (15) & 26 & (1) & 26 & 25 \\
\hline \multicolumn{7}{|l|}{ Defined benefit plans } \\
\hline Net prior service cost & - & - & - & & & \\
\hline Net actuarial loss & 3 & (1) & 2 & & & \\
\hline $\begin{array}{l}\text { Total pension and other } \\
\text { postretirement obligations }\end{array}$ & 3 & (1) & 2 & (59) & 2 & (57) \\
\hline Total & $\$ 83$ & (30) & 53 & (179) & 53 & (126) \\
\hline
\end{tabular}

Source: Fifth Third Bancorp, 2007 Annual Report, p. 75

As evidenced in both of these sample disclosures, most banks report both the pretax and after-tax reclassifications. For those that report only the pre-tax reclassifications, we use the standard federal tax rate of $35 \%$ to calculate the after-tax reclassifications.

\section{References}

Abdel-Khalik, R. (2008). The case against fair value accounting. SEC Comment Letter, 4-573.

Ahmed, A., \& Takeda, C. (1995). Stock market valuation of gains and losses on commercial banks' investment securities: An empirical analysis. Journal of Accounting and Economics, 20, 207-225.

Badertscher, B., Burks, J., \& Easton, P. (2012). When a loss is more than just a loss: The market pricing of other-than-temporary impairments. Working paper, University of Notre Dame.

Bamber, L., Jiang, J., Petroni, K., \& Wang, I. (2010). Comprehensive income: Who's afraid of performance reporting. The Accounting Review, 85(1), 97-126.

Barnea, A., Ronen, J., \& Sadan, S. (1976). Classificatory smoothing of income with extraordinary items. The Accounting Review, 51(1), 110-122.

Barth, M. (1994). Fair value accounting: Evidence from investment securities and the market valuation of banks. The Accounting Review, 69(1), 1-25.

Barth, M., Beaver, W., \& Landsman, W. (1996). Value-relevance of banks' fair value disclosures under SFAS No. 107. The Accounting Review, 71(4), 513-537.

Beatty, A., Chamberlain, S., \& Magliolo, J. (1995). Managing financial reports of commercial banks: The influence of taxes, regulatory capital and earnings. Journal of Accounting Research, 33, 231-261.

Beatty, A., Ke, B., \& Petroni, K. (2002). Earnings management to avoid earnings declines across publicly and privately held banks. The Accounting Review, 77, 547-570.

Biddle, G., \& Choi, J. H. (2006). Is comprehensive income useful? Journal of Contemporary Accounting and Economics, 2, 1-32.

Chambers, D., Linsmeier, T., Shakespeare, C., \& Sougiannis, T. (2007). An evaluation of SFAS No. 130 comprehensive income disclosures. Review of Accounting Studies, 12, 557-593.

Chang, Y., Liu, C., \& Ryan, S. (2011). Why banks elected SFAS No. 159's fair value option: Opportunism versus compliance with the standard's intent. Working paper, New York University.

Collins, J., Shackelford, D., \& Wahlen, J. (1995). Bank differences in the coordination of regulatory capital, earnings, and taxes. Journal of Accounting Research, 33, 263-291.

Cornett, M., McNutt, J., \& Tehranian, H. (2009). Corporate governance and earnings management at large U.S. bank holding companies. Journal of Corporate Finance, 15(4), 412-430. 
Dhaliwal, D., Subramanyam, K., \& Trezevant, R. (1999). Is comprehensive income superior to net income as a measure of firm performance? Journal of Accounting and Economics, 26, 43-67.

Easton, P., \& Sommers, G. (2003). Scale and the scale effect in market-based accounting research. Journal of Business Finance and Accounting, 30(1-2), 25-56.

Eccher, A., Ramesh, K., \& Thiagarajan, S. (1996). Fair value disclosures by bank holding companies. Journal of Accounting and Economics, 22, 79-117.

Fama, E., \& French, K. R. (1992). The cross-section of expected stock returns. Journal of Finance, 47, 427-465.

Fama, E., \& French, K. R. (1993). Common risk factors in the returns on stocks and bonds. Journal of Financial Economics, 33, 3-56.

Financial Accounting Standards Board. (1991). Disclosures about fair value of financial instruments. Statement of Financial Accounting Standards No. 107, Stanford, CT.

Financial Accounting Standards Board. (1993). Accounting for certain investments in debt and equity securities. Statement of Financial Accounting Standards No. 115, Stanford, CT.

Financial Accounting Standards Board (FASB). (1997). Reporting comprehensive income. Statement of Financial Accounting Standards No. 130, Stanford, CT.

Financial Accounting Standards Board (FASB). (2010). Accounting for financial instruments and revisions to the accounting for derivative instruments and hedging activities. Exposure draft. Stanford, CT: Financial Accounting Standards Board.

Forbes, S. (2009). End market-to-market. Forbes.com. March 29, 2009.

Hand, J., \& Landsman, W. (1998). Testing the Ohlson model: $v$ or not $v$, that is the question. Working paper, University of North Carolina.

Holthausen, R., \& Watts, R. (2001). The relevance of the value-relevance literature for financial accounting standard setting. Journal of Accounting and Economics, 31, 3-75.

Jegadeesh, N., \& Titman, S. (1993). Returns to buying winners and selling losers: Implications for stock market efficiency. Journal of Finance, 48, 65-91.

Johnson, L., \& Swieringa, R. (1996). Anatomy of an agenda decision: Statement No. 115. Accounting Horizons, 10, 149-179.

Khan, U. (2010). Does fair value accounting contribute to systemic risk in the banking industry? Working paper, Columbia Business School.

Lakonishok, J., Shleifer, A., \& Vishny, R. (1994). Contrarian investment, extrapolation, and risk. Journal of Finance, 49, 1541-1578.

Moyer, S. (1990). Capital adequacy ratio regulation and accounting choices in commercial banks. Journal of Accounting and Economics, 13(2), 123-154.

Nelson, K. (1996). Fair value accounting for commercial banks: An empirical analysis of SFAS No. 107. The Accounting Review, 71, 161-182.

Nissim, D., \& Penman, S. (2008). Principles for the application of fair value accounting. Columbia Business School Center for Excellence in Accounting \& Security Analysis White Paper No. 2, July.

O'Hanlon, J., \& Pope, P. (1999). The value relevance of U.K. Dirty Surplus Accounting Flows, British Accounting Review, 31, 459-482.

Ohlson, J. (1995). Earnings, book values, and dividends in equity valuation. Contemporary Accounting Research, 11, 661-687.

Penman, S., \& Zhang, X. (2002). Accounting conservatism, the quality of earnings, and stock returns. The Accounting Review, 77(2), 237-264.

Petersen, M. A. (2009). Estimating standard errors in finance panel data sets: Comparing approaches. Review of Financial Studies, 22, 435-480.

Rees, L., \& Shane, P. (2012). Academic research and standard setting: The case of other comprehensive income. Accounting Horizons, 26(4), 789-815.

Ronen, J. (2008). To fair value or not to fair value: A broader perspective. Abacus, 44, 181-208.

Ronen, J., \& Sadan, S. (1981). Smoothing income numbers: Objectives, means, and implications. Boston, MA: Addison-Wesley Publishing Company.

Schipper, K. (2007). Required disclosure in financial reports. The Accounting Review, 82, 301-326.

Scholes, M., Wilson, G., \& Wolfson, M. (1990). Tax planning, regulatory capital planning, and financial reporting strategy for commercial banks. Review of Financial Studies, 3, 625-650.

Schultz, S., \& Hollister, J. (2003). Lobbying FASB on accounting for investments. The Journal of Applied Business Research, 19, 85-99.

Sloan, R. (1996). Do stock prices fully reflect information in accruals and cash flows about future earnings? The Accounting Review, 71(3), 289-315. 
Teoh, S., Welch, I., \& Wong, T. (1998). Earnings management and the underperformance of seasoned equity offerings. Journal of Financial Economics, 50, 63-99.

Wallison, P. (2008). Judgment too important to be left to the accountants. Financial Times. May 1, 2008.

Warfield, T., \& Linsmeier, T. (1992). Tax planning, earnings management, and the differential information content of bank earnings components. The Accounting Review, 67(3), 546-562.

Watts, R. (1993). A proposal for research on conservatism, University of Rochester Financial Research and Policy Working Paper Series FR 93-13, May. 